\title{
A 100-Year Review: Protein and amino acid nutrition in dairy cows ${ }^{1}$
}

\author{
Charles G. Schwab ${ }^{\star 2,3}$ and Glen A. Broderickt \\ *Schwab Consulting LLC, 105 Doc Mac Drive, Boscobel, WI 53805 \\ †Broderick Nutrition \& Research LLC, 221 Glen Hollow Road, Madison, WI 53705
}

\begin{abstract}
Considerable progress has been made in understanding the protein and amino acid (AA) nutrition of dairy cows. The chemistry of feed crude protein (CP) appears to be well understood, as is the mechanism of ruminal protein degradation by rumen bacteria and protozoa. It has been shown that ammonia released from AA degradation in the rumen is used for bacterial protein formation and that urea can be a useful $\mathrm{N}$ supplement when lower protein diets are fed. It is now well documented that adequate rumen ammonia levels must be maintained for maximal synthesis of microbial protein and that a deficiency of rumen-degradable protein can decrease microbial protein synthesis, fiber digestibility, and feed intake. Rumen-synthesized microbial protein accounts for most of the CP flowing to the small intestine and is considered a high-quality protein for dairy cows because of apparent high digestibility and good AA composition. Much attention has been given to evaluating different methods to quantify ruminal protein degradation and escape and for measuring ruminal outflows of microbial protein and rumen-undegraded feed protein. The methods and accompanying results are used to determine the nutritional value of protein supplements and to develop nutritional models and evaluate their predictive ability. Lysine, methionine, and histidine have been identified most often as the most-limiting amino acids, with rumen-protected forms of lysine and methionine available for ration supplementation. Guidelines for protein feeding have evolved from simple feeding standards for dietary $\mathrm{CP}$ to more complex nutrition models that are designed to predict supplies and requirements for rumen ammonia and peptides and intestinally absorbable AA. The industry awaits more robust and mechanistic models for predict-
\end{abstract}

Received June 12, 2017.

Accepted August 22, 2017.

${ }^{1}$ This review is part of a special issue of the Journal of Dairy Science commissioned to celebrate 100 years of publishing (1917-2017).

${ }^{2}$ Corresponding author: charles.schwab@unh.edu

${ }^{3}$ Professor Emeritus, Department of Animal Science, University of New Hampshire, Durham 03824. ing supplies and requirements of rumen-available $\mathrm{N}$ and absorbed AA. Such models will be useful in allowing for feeding lower protein diets and increased efficiency of microbial protein synthesis.

Key words: nutrition, amino acids, dairy cows, 100year review

\section{INTRODUCTION}

Dietary protein generally refers to crude protein $(\mathrm{CP})$, defined for feedstuffs as the nitrogen content multiplied by a factor of 6.25 . This factor is based on the fact that most proteins contain $16 \% \mathrm{~N}$. The calculated $\mathrm{CP}$ content includes both protein and nonprotein $\mathrm{N}(\mathrm{NPN})$. As one of the original 6 proximate nutrients, the analysis of which was established over $150 \mathrm{yr}$ ago at the Weende Experiment Station in Germany, CP became an established nutrient for dairy cows. Although $\mathrm{CP}$ is still considered by dairy nutritionists in ration formulation, papers published in the Journal of Dairy Science (JDS) beginning over $60 \mathrm{yr}$ ago started to provide evidence of the shortcomings of relying on $\mathrm{CP}$ as a nutrient for which requirements could be narrowly defined. As a result of this research, protein nutrition of dairy cows has moved past the use of dietary CP as a targeted nutrient and is now focused on meeting the ammonia and AA needs of ruminal fermentation for microbial protein synthesis and the AA requirements of the cow. The objective of this paper is to highlight the major discoveries in protein and AA nutrition as reported in JDS during its 100-yr history and how that has influenced protein feeding of dairy cows (Appendix Table A1).

\section{MAJOR DISCOVERIES AND ACCOMPLISHMENTS}

\section{Before 1917}

Much of the knowledge of animal protein nutrition before 1917 can be found in an early edition of Feeds and Feeding (Henry and Morrison, 1917). It was recognized at that time that dietary proteins provided AA to the animal and that proteins differed in nutritional value because of differences in AA composition. It was 
also known that enzymes were needed for protein digestion and that AA had to be released before intestinal absorption could occur. Finally, it was understood that absorbed AA were carried via the blood to the various tissues of the body for protein synthesis. Henry and Morrison speculated "that if a feeding stuff contains all of the AA (the protein building-stones) to form body protein, these amids [AA] could be used in the same manner as true protein for the repair of body tissue or for the formation of new protein tissue." Protein AA were also known to be metabolized to glucose and, via glucose, could be used for energy and fat synthesis. Proper digestion in the ruminant was said to require $12.5 \%$ digestible protein to be present in the total digestible nutrients (TDN) to "feed the bacteria" so they could digest cellulosic material in the rumen. However, the contribution of rumen bacteria to the AA requirements of the animal appears to have been completely ignored. So in 1917, there was still a very large vacuum on protein and AA nutrition that required filling.

\section{The First 5 Protein-Related Papers}

In the first nutrition-related paper published in JDS, Woll (1918) reviewed research that indicated that the high content of CP in alfalfa was important to alfalfa's superiority as a forage for growth and milk production. Two years later, in the first JDS paper to mention feeding standards for dairy cattle, McCandlish (1920) reviewed the efforts of others and put forth a revised set of requirements for amounts of digestible $\mathrm{CP}$ and digestible carbohydrate equivalents needed to produce $1 \mathrm{lb}$ of milk with varying percentages of milk fat. The following year, in 2 uncharacteristically long papers, Nevens $(1921 \mathrm{a}, \mathrm{b})$ summarized (1) the efforts of the previous 40 years in trying to isolate and quantify proteins, NPN compounds, and AA in feeds; (2) the results of an experiment comparing the distribution of $\mathrm{N}$ among various NPN and protein fractions in cottonseed meal, the AA composition of the extracted proteins, and a comparison of these values with those for alfalfa hay, oats and corn; and (3) the results of an experiment using laboratory rats to study the relative nutritive value of the proteins of alfalfa hay and corn with cottonseed meal. A year later, McCandlish and Weaver (1922) compared coconut, peanut, and soybean meals with gluten feed as protein supplements for dairy cows. These 5 papers are mentioned to highlight that it has long been known that the CP content of forages influences the amount of supplemental protein needed in the diet, that feed $\mathrm{CP}$ represents a wide variety of proteins and $\mathrm{N}$ constituents, and that protein supplements are not created equal and vary in nutritive value.

\section{The Chemistry of Feed CP}

As noted, it was known before 1917 that CP was a "proximate" nutrient and that it included numerous proteins and NPN compounds. With advancements in chemistry and isolation techniques, it was discovered that proteins differed in size, shape, solubility, function, digestibility, and AA composition, and that feeds differed in the relative amounts of the different protein types that they contained. It was also discovered that feed NPN was composed of many different low-molecular-weight compounds such as peptides, free AA, nucleic acids, amides, amines, and ammonia. And finally, it was found that grass and legume forages contained the highest and most variable concentrations of NPN and that hays, and especially silages, contained more NPN than the same feed when fresh. See Chapter 5 in NRC (2001) for a more detailed discussion on these findings and associated references.

\section{Feeding Supplemental NPN}

Utilization of urea and other NPN sources as dietary $\mathrm{CP}$ was the first major topic on protein nutrition addressed in JDS. It was previously theorized by Zuntz (1891, cited by Loosli et al., 1949) that rumen bacteria could use urea $\mathrm{N}$ for synthesis of protein, and that this protein was retained in the tissues of growing cattle. However, much of the early work on the benefits of urea feeding was often conflicting because urea was often added to diets already adequate in CP. The definitive, early work of Hart et al. (1939) helped clarify the situation. These workers fed growing calves basal diets with $6 \% \mathrm{CP}$ to which was added sufficient urea, ammonium bicarbonate, or casein to increase total $\mathrm{CP}$ to about $18 \%$. Improvement in weight gain over the basal control on either urea or ammonium bicarbonate averaged $29 \%$ of that with casein in 2 trials. The same workers showed that, using ruminal in vitro incubations, urea was completely broken down to ammonia and the ammonia was used for bacterial protein formation (Wegner et al., 1940). A subsequent study by Rupel et al. (1943) compared milk yield (over 15 complete lactations on each treatment) on a basal concentrate mix with $10 \%$ $\mathrm{CP}$ with 2 other concentrate mixes containing $18 \% \mathrm{CP}$; the additional CP was supplied as urea or linseed meal. Yield of 4\% FCM was increased 14 and 19\%, respectively. The response to linseed meal was reported to be greater than the response to urea $(P \approx 0.05)$ - an early application of statistics to nutritional results reported in JDS. It is also noteworthy that, in that study, urea was supplemented at $3 \%$ of the concentrate mix DM, corresponding to about $1 \%$ of total ration DM-a rule 
of thumb for urea feeding that was taught to students of animal nutrition at least until the mid-1960s.

Since that time, many JDS papers have dealt with feeding a portion of the dietary CP as urea. Van Horn et al. (1969) found that adding urea to an all-corn silage diet to raise CP from 7 to $11 \%$ increased milk yield by about $2 \mathrm{~kg} / \mathrm{d}$ in Jerseys, whereas replacing soybean meal with urea in $13.5 \% \mathrm{CP}$ diets reduced milk yield by $2.5 \mathrm{~kg} / \mathrm{d}$ in Holsteins. Moreover, cows on the urea diet also lost BW. Holter et al. (1968) reported that replacing 4 percentage units of $\mathrm{CP}$ as true protein in an $18 \% \mathrm{CP}$ grain mix with urea had no effect on milk yield in a commercial dairy with an impressive (for the time) 305-d mature-equivalent rolling herd average of $8,044 \mathrm{~kg}$. Perusal of reviews by Reid (1953) and Helmer and Bartley (1971) illustrate how knowledge, philosophy, and recommendations on urea supplementation evolved as milk yield and dietary protein concentrations increased. To assist with recommendations on urea supplementation, Roffler and Satter (1975a,b) developed and evaluated a model for predicting NPN utilization by growing cattle and lactating dairy cows.

\section{Importance of Maintaining Adequate Rumen Ammonia Levels}

Discussion of feeding urea would not be complete without touching on the controversy between University of Wisconsin and Michigan State researchers on the "required" rumen ammonia concentration for optimal microbial protein formation in the rumen. Using continuous culture fermentors, Satter and Slyter (1974) observed that ammonia concentrations in excess of 5 $\mathrm{mg}$ of N/dL had no added benefit on microbial protein yields. Ruminal measurements in lactating cows indicated that mean ammonia concentrations of $5 \mathrm{mg}$ of $\mathrm{N} /$ $\mathrm{dL}(3.6 \mathrm{~m} M)$ were obtained on lactation diets containing 12 to 13\% CP (Satter and Roffler, 1975). Satter and colleagues thus concluded there would be no benefit to supplementing higher CP rations with urea. However, J. T. Huber and his group reported that, compared with feeding diets based on corn silage containing 11 to $12 \% \mathrm{CP}$, replacing the conventional corn silage with urea-treated or ammoniated corn silage improved milk yield (Huber, 1975). Although Huber (1975) did not report ruminal ammonia concentrations, higher energy density may have resulted in lower ammonia concentrations at comparable dietary CP levels in Huber's corn silage-based diets compared with those in Satter's in vivo database. Inspecting both of the 1975 papers indicates that Satter and Huber were not in great disagreement.
Erdman et al. (1986) evaluated effects of ruminal ammonia concentration on in situ digestion of ground corn, soybean meal, corn gluten feed, cottonseed meal, and alfalfa hay in the rumens of dry Holstein cows fed a $7.4 \% \mathrm{CP}$ diet. Continuous ruminal infusion of 0,33 , 67 , and $100 \mathrm{~g} / \mathrm{d}$ of urea $\mathrm{N}$ resulted in mean ruminal ammonia concentrations of $3.0,7.2,12.2$, and $17.8 \mathrm{mM}$. Effective DM degradation increased linearly for ground corn and soybean meal, but was maximized at the third urea level for corn gluten feed and cottonseed meal. Alfalfa hay NDF degradation was not increased with urea infusion. Erdman et al. (1986) concluded from this and previous research that the minimum ruminal ammonia concentrations needed to maximize in situ digestion depended on feed fermentability and was higher when potential fermentability was higher rather than lower. This conclusion was supported by the finding that higher ruminal ammonia concentrations were needed to maximize in situ digestion rate of ground barley (8.9 $\mathrm{m} M$ ) than ground corn (4.3 $\mathrm{m} M$; Odle and Schaefer, 1987).

Schwab et al. (2005) reviewed the literature on $\mathrm{N}$ requirements of ruminal microorganisms, summarizing that (1) ruminal ammonia concentrations of 5 to $11 \mathrm{~m} M$ were needed to maximize flows of microbial $\mathrm{N}$ from the rumen depending on diet and fermentation conditions; (2) the optimum concentration of ruminal ammonia appeared to be diet dependent and influenced by factors such as type of $\mathrm{N}$ supplements and carbohydrate fermentability and possibly factors affecting passage rates (e.g., DMI); (3) increasing amounts of ruminal $\mathrm{N}$ losses occurred with increasing ammonia concentrations; (4) the ammonia concentrations required to maximize ruminal $\mathrm{OM}$ digestion were at least as high as those required to maximize ruminal synthesis of microbial protein; (5) not only was average ammonia concentration important, but also the time the concentration fell below some critical level; and (6) higher ruminal ammonia concentrations may be needed if more readily fermentable carbohydrates were fed. Experiments since the literature review by Schwab et al. (2005) have shown that a deficiency of RDP in dairy cows can decrease total-tract digestibility of fiber and DMI (e.g., Lee et al., 2012; Giallongo et al., 2015). Additionally, Bach et al. (2005) demonstrated a quadratic relationship between efficiency of bacterial protein synthesis and efficiency of $\mathrm{N}$ utilization in continuous culture fermentor studies, with mean maximal efficiency of $\mathrm{N}$ usage by ruminal bacteria (69\%) occurring at an efficiency of microbial protein synthesis of 29 $\mathrm{g}$ of bacterial $\mathrm{N} / \mathrm{kg}$ of OM fermented. Clearly, adequate amounts of rumen-available $\mathrm{N}$ are needed to optimize 
rumen function and maximize synthesis of microbial protein.

\section{Microbial Protein Metabolism in the Rumen}

That microbial protein could provide all of the AA needed for milk protein synthesis was provided by Virtanen (1966) when he found that all milk protein AA were enriched with ${ }^{15} \mathrm{~N}$ when the rumen was dosed with $\left({ }^{15} \mathrm{NH}_{4}\right)_{2} \mathrm{SO}_{4}$. The magnitude of the contribution of the ruminal microbes to the AA requirements of the animal was apparent from trials in which ruminants were fed diets where all dietary CP was supplied by urea and ammonium salts (e.g., Virtanen, 1966; Oltjen, 1969). Although these animals could reproduce, the growth rates, feed efficiency, and $\mathrm{N}$ retention of growing cattle were reduced, on average, by $35 \%$ compared with feeding the same diets but with all $\mathrm{CP}$ equivalent provided by isolated soy protein (Oltjen, 1969). Although it is now known that isolated soy protein is extensively degraded in the rumen and would provide relatively little RUP, it is also known that the peptides and free AA released from degradation of true proteins stimulate microbial protein synthesis in the rumen (Russell et al., 1992). Essential AA concentrations in blood plasma were depressed in lactating cows fed the all-NPN CP diets (Virtanen, 1966). Thus, it became clear that quantifying microbial protein formation, including factors influencing its supply, was of major importance in dairy cattle nutrition.

Much of the earliest research on microbial protein metabolism in the rumen was conducted in sheep in the United Kingdom in the decades following World War II. McDonald (1952) observed that ammonia was a major end product of ruminal protein degradation. Subsequently, McDonald and Hall (1954) followed ruminal casein degradation by tracking disappearance of protein-bound phosphate; this work showed that more than $90 \%$ of dietary casein was degraded in the rumen and that the degradation products were used for microbial protein formation. Chalmers et al. (1954) showed that casein was poorly utilized for $\mathrm{N}$ retention when fed or administered via ruminal cannula in sheep; however, a much greater proportion of casein $\mathrm{N}$ administered via duodenal cannula was retained. Moreover, feeding heat-treated casein gave rise to less ruminal ammonia and increased N retention. Annison (1956) found that certain proteins (e.g., casein) were rapidly and extensively degraded in the rumen via initial formation of dialyzable peptides, then to free AA, and finally to ammonia, whereas other proteins (e.g., zein) were slowly degraded by ruminal microbes. Additionally, it was observed that rates of ruminal disappearance of ammonia and free AA were related to intake of fermentable carbohydrates by the sheep. A more detailed description of the mechanism of ruminal protein degradation is presented in NRC (2001).

The above-mentioned trials served as the basis for the development of methods to increase ruminal escape of dietary proteins. Australian research developed formaldehyde treatment as a technique to increase the RUP content of proteins fed to ruminants (Ferguson et al., 1967). Although this method is no longer used in the United States, heat treatment has evolved as the principal method for reducing ruminal degradation of feed proteins (Schwab, 1995) and is widely applied to improve RUP in soybean meal (e.g., Broderick et al., 1990), whole soybeans (e.g., Faldet and Satter, 1991), and other protein supplements fed to lactating dairy cows.

\section{Nutritive Value of Microbial Protein}

Ruminally synthesized microbial protein derives from a mixture of bacteria, protozoa, and fungi that multiply in the rumen and flow with the ruminal digesta to the lower gastrointestinal tract. Over 200 species of bacteria, more than 20 species of protozoa, and at least 12 species of fungi have been found in the rumen. It is known from numerous experiments that microbial protein usually accounts for more than $50 \%$ of the $\mathrm{CP}$ flowing to the small intestine. Therefore, it is important to know the chemical composition of the $\mathrm{CP}$ fraction of the microorganisms and their contribution to the AA supply of the animal.

Early research indicated that the distribution of $\mathrm{N}$ in ruminal bacteria was variable and influenced by species and conditions of growth. For example, data from 62 literature reports indicated that, as a proportion of total N, AA-N averaged $82.5 \%(\mathrm{SE}=28.3)$, RNA-N averaged $10.0 \%(\mathrm{SE}=8.3)$, and $\mathrm{DNA}-\mathrm{N}$ averaged $5.2 \%(\mathrm{SE}$ $=9.4)$ (Storm and Ørskov, 1983). A literature review by Clark et al. (1992) involving 34 observations indicated that AA-N constituted an average of only $66.5 \%$ of total $\mathrm{N}$ (range $=54.9$ to $86.7 \%$ ). Ruminal protozoa contained more AA-N, relative to total $\mathrm{N}$, than ruminal bacteria because of lower concentrations of nucleic acid $\mathrm{N}$ (about $11 \%$ rather than $15 \%$ of total $\mathrm{N}$ ) and cell wall-associated NPN compounds (Ørskov, 1992).

Of greatest importance to understanding the nutritive value of mixed microbial protein to the animal and for the development of nutritional models is knowing the AA composition of the bacteria and protozoa and the intestinal digestibility of their AA. Many researchers have reported the AA composition of isolated rumen bacteria and protozoa. Sok et al. (2017) reviewed the literature and, using only data from cattle, reported average AA composition values for fluid-associated 
bacteria, particle-associated bacteria, and protozoa. Some important results were reported. First, total AA accounted for an average of $82.4 \%$ of $\mathrm{CP}$ in bacteria, a value slightly higher than the $80 \%$ used in several nutritional models. Second, composition differed between protozoa and bacteria for 5 of the $10 \mathrm{EAA}$. By far, the largest difference was the $42 \%$ lower Lys concentration in bacteria than protozoa. And finally, the small differences found between fluid-associated and particleassociated bacteria were less than the differences between bacteria and protozoa. These findings highlight the need for more research to better understand the effect of diet composition on the relative contributions of AA from these 3 major populations of ruminal microorganisms.

There have been few direct determinations of the intestinal digestibility of ruminally synthesized microbial protein. Storm et al. (1983) infused incremental levels of freeze-dried preparations of ruminal bacteria into the abomasums of sheep sustained entirely by intragastric infusion. True digestibility of individual AA was estimated by regressing bacterial AA input on passage to the ileum. Values ranged from 68 to $88 \%$, with an average digestibility value of $85 \%$. By using the same approach but with sheep fed conventional diets, Tas et al. (1981) calculated microbial AA digestibility to be $87 \%$.

Mixed microbial protein is generally considered to be of good quality for dairy cattle. This is because of high apparent digestibility and an EAA composition similar to that of lean body tissue and milk. However, Virtanen (1966) noted that, in studies where NPN provided all dietary $\mathrm{CP}$, His was depressed in blood plasma of lactating cows and was the milk AA with lowest ${ }^{15} \mathrm{~N}$ enrichment. This suggested that ruminal microbial protein may be a poor source of metabolizable His, an issue we will address later.

\section{Nitrogen Recycling and Its Benefits with Low-CP Diets}

Several early studies conducted with sheep indicated that feeding low- versus high-CP diets yielded essentially equal wool growth and similar amounts of true protein passing to the small intestine (Ferguson, 1959; Hogan and Weston, 1967). The effect of ruminal microbial metabolism was to essentially equalize the 2 diets, with more protein leaving the rumen than was consumed on the low-CP diet. This occurred because of urea recycling back to the rumen (via the saliva and directly across the ruminal wall from blood) and the urea being salvaged and again used for microbial protein synthesis (Houpt, 1959; Cocimano and Leng, 1967).
Two excellent reviews have been published on $\mathrm{N}$ recycling in ruminants (Lapierre and Lobley, 2001; Reynolds and Kristensen, 2008). Although N recycling has been shown to be clearly advantageous to ruminants consuming low-protein diets, it has been concluded that more research is needed to fully exploit this phenomenon when feeding for maximal or near-maximal milk production (Calsamiglia et al., 2010). For the most part, experiments aimed at trying to increase efficiency of use of dietary $\mathrm{N}$ by increasing urea recycling have not been successful. Research indicates that the amount of recycled $\mathrm{N}$ used for anabolic purposes is determined primarily by microbial requirements and factors affecting efficiency of microbial protein synthesis (Reynolds and Kristensen, 2008).

\section{Measuring Ruminal Outflows of Microbial Protein and RUP}

A large body of literature in JDS and other journals report measurements of ruminal outflow of microbial protein and RUP in dairy cows and growing cattle cannulated in the abomasum or proximal duodenum. In some of these experiments, AA passage was also measured. The first of these experiments were conducted in the early 1980s (e.g., Arambel and Coon, 1981; Stern et al., 1983; Prange et al., 1984; Santos et al., 1984), with most of the publications occurring in the 1990s and the last 2 in 2005 (Ipharraguerre et al., 2005a,b). Among the markers used to distinguish microbial protein from RUP were nucleic acids, diaminopimelic acid, and ${ }^{15} \mathrm{~N}$ incorporation from ammonium salts infused into the rumen (Broderick and Merchen, 1992); of these, ${ }^{15} \mathrm{~N}$ incorporation is the most theoretically sound. A variety of different liquid- and solid-phase markers have been used to measure digesta flow.

Placing and maintaining cannulas in the abomasum or duodenum can be problematic. A major breakthrough in this area was the development of the omasal sampling technique, which uses a device that alternatively applies vacuum and pressure to allow collection of digesta from the omasum via a tube inserted through the ruminal cannula (Huhtanen et al., 1997; Ahvenjärvi et al., 2000). The technique also uses triple marker methodology (Armentano and Russell, 1985; France and Siddons; 1986) to compute passage of fluid, small-particle, and large-particle phases. The procedure is less invasive than abomasal or duodenal cannulation and has been applied extensively in lactating dairy cows to assess factors influencing both RUP and microbial protein formation (e.g., Broderick et al., 2010). Recent evidence indicates that satisfactory estimates of nutrient outflow from the rumen can also be made 
using reticular sampling, which obviates the need for the alternating vacuum-pressure device. For example, Krizsan et al. (2010) reported similar ruminal nutrient outflows with only estimates of ruminal NDF digestibility differing between sampling from the omasum (74\%) and reticulum (71\%).

The information provided by these experiments has been exceptionally useful for building nutritional models (e.g., NRC, 2001), for evaluating their predictive ability (e.g., Pacheco et al., 2012; White et al., 2017a,b), and for deriving new prediction equations (e.g., White et al., 2017a,b). Table 5-11 in NRC (2001) lists the experiments with dairy cows and growing cattle that were used to develop regression equations for predicting AA passage in the NRC (2001) model. The appendix table in Pacheco et al. (2012) is an updated list of trials that is exclusive to dairy cows with differing dietary treatments. The collection of papers used by White et al. $(2017 \mathrm{a}, \mathrm{b})$ was further updated with work published through mid-2015, containing 550 treatment means from 147 studies conducted on lactating or dry cows.

\section{Solubility and In Situ Assays to Quantify Ruminal Protein Degradation and Escape}

It has long been understood that the value of a protein fed to ruminants is influenced substantially by the extent to which it is degraded in the rumen and that methods were needed to quantify the amounts of RDP and RUP in feed ingredients. This was eventually made very apparent by Santos et al. (1998), who reviewed results from 29 ruminal outflow studies and reported that replacing soybean meal with isonitrogenous amounts of high-RUP sources reduced microbial protein flow $76 \%$ of the time, an effect attributed to inadequate RDP supply. Clearly, optimizing $\mathrm{N}$ efficiency in dairy production requires that sufficient $\mathrm{RDP}$ be provided to support microbial formation in the rumen.

Ideally, protein degradation in the rumen should be determined in vivo in lactating cows at normal DM intakes of 3 to 4 times maintenance. Successful application of omasal sampling in dairy cows with typical DM intakes is one of the principal advantages of that method. Of course, in vivo measurements are impractical for routine use and can only be applied experimentally and to supplement laboratory methods for feed analysis. Correlations between protein solubility and ruminal degradation were recognized in the 1950s and 1960s and determining protein solubility in rumen-like buffers became a proxy for protein degradation in the rumen (e.g., Crooker et al., 1978). Different buffers were tested and Burroughs' buffer was recommended as that most related to $\mathrm{N}$ disappearance from Dacron bags in short-term incubations (Crawford et al., 1978). Dur- ing that era, $\mathrm{N}$ solubility actually became synonymous with ruminal protein degradability. However, certain soluble proteins were known to be slowly degraded; for example, Annison (1956) found that serum albumin, which was more buffer soluble than casein, had a slower rate of ammonia formation in ruminal in vitro incubations.

In situ incubations had been used for many years to assess fiber as well as protein degradation. But it was the work of Ørskov, particularly the report describing the mathematical methods to compute degradation rate and extent from in situ data (Ørskov and McDonald, 1979), that popularized this method of estimating protein degradability. From the outset, there was concern about $\mathrm{N}$ loss from in situ bags for reasons other than protein degradation, such as small particle loss and leakage of soluble $\mathrm{N}$, which would lead to overestimation of degradation rates. Moreover, increase in $\mathrm{N}$ within the in situ bag due to microbial growth would lead to underestimation of degradation rates. Despite recognition of these limitations, it was clear that results were correlated with in vivo rates and extents of protein degradation (Stern and Satter, 1984). The in situ model was adopted to build the protein model in NRC (2001).

It must be noted that there is currently strong interest in moving away from the in situ assay as the standard for estimating protein degradation because of incorrect evaluation of certain feeds. For example, soybean meal and canola meal have in situ RUP values of 43 and $36 \%$, respectively, at $\mathrm{DMI}=4 \%$ of $\mathrm{BW}$ (NRC, 2001). However, lower in vivo ruminal concentrations of the protein breakdown products ammonia and branchedchain VFA (Broderick et al., 2015) and lower ruminal in vitro estimates of degradation (Broderick et al., 2016) indicate that canola meal protein is substantially less degradable than soybean meal protein. Ring studies have been conducted comparing in situ results from different laboratories (Madsen and Hvelplund, 1994; Mathis et al., 2001).

\section{In Vitro and Protease Assays to Quantify Ruminal Protein Degradation and Escape}

Ruminal in vitro methods would be an obvious choice to estimate protein degradability because they utilize the actual organisms involved in degradation. Assessing extent of degradation can be done from appearance of the peptides, free AA, and ammonia released during protein breakdown; however, these compounds are also taken up for microbial growth. One of us (GAB) addressed this issue by adding inhibitors of microbial $\mathrm{N}$ metabolism that allowed, in short incubations, quantitative recovery of protein degradation products 
(Broderick, 1987). A variation of this method applied Michaelis-Menten kinetics to degradation data to compute RUP values (Colombini et al., 2011). Although well correlated with in vivo RUP for several feedstuffs, both variants of the inhibitor in vitro method are tedious and inappropriate for routine laboratory application. A modified ruminal in vitro gas production method was developed by Raab et al. (1983), who quantified degradation from ammonia formation, using gas production to account for $\mathrm{N}$ incorporated into microbial cells. This assay was modified and upgraded by Karlsson et al. (2009).

The advantage of using isolated proteases to assess protein degradability is that this obviates the need for ruminally cannulated animals. A large body of literature has developed using these approaches and we will consider only selected papers. Mahadevan et al. (1980) isolated protease from cultures of the ruminal organism Bacteroides amylophilus (now Ruminobacter amylophilus) and incubated it with several soluble and insoluble proteins. Among the findings were that 2 soluble proteins, serum albumin and ribonuclease A, were slowly degraded, and both soluble and insoluble proteins extracted from soybean meal were degraded at similar rates. Nocek et al. (1983) assessed degradation from rates of AA release from soluble and insoluble proteins using Streptomyces griseus protease (SGP), a commercially available enzyme mixture; degradation rates for soluble proteins were found to be 2 to 3 times faster than for insoluble proteins from the same feedstuff. Krishnamoorthy et al. (1983) also used SGP to estimate protein degradation rates. Another example of thorough work in this area is that of Poos-Floyd et al. (1985), who compared in vitro degradation of 9 proteins using 5 commercial proteases (including SGP) with buffer solubility in 5 solvents, in situ degradability, and in vivo degradability estimated from the literature and from growth rates of lambs and steers. The proteases were incubated at equivalent activity for various lengths of time, and residual $\mathrm{N}$ remaining after enzyme digestion was measured. All 5 proteases yielded results that were highly correlated with in vivo RUP estimates, but the strength of the correlations declined as incubations were extended from 1 to $24 \mathrm{~h}$. Of the 5 proteases tested, neutral fungal protease had the highest correlation to in vivo degradation and the lowest variation; however, this protease also degraded the least amount of protein. Mahadevan et al. (1987) observed substantially different degradation rates using proteases extracted from mixed ruminal organisms and SGP.

More recent papers dealing with using commercial proteases to assess ruminal degradability include those of Roe et al. (1991), Coblentz et al. (1999), and Miraz and Miller (2005). Generally, in vitro protease degradation rates measured from solubilized $\mathrm{N}$ were, not surprisingly, well correlated with in situ degradation rates where $\mathrm{N}$ solubilization is an important factor in $\mathrm{CP}$ degradation rates. Correlations were not as good when AA release was the criterion for degradation using proteases; this indicated that specificity of commercial proteases is not similar to the proteases elaborated by the mixed organisms in the rumen. Edmunds et al. (2012) used SGP to estimate degradation rates of the insoluble CP in 25 forages to predict in situ RUP values. A recent review of laboratory methods for quantifying ruminal protein degradation and escape is given in Broderick and Colombini (2010).

\section{Nutritive Value of the RUP Fraction of Feed Proteins}

It is understood that the AA composition and intestinal digestibility of RUP will determine its nutritive value to the animal. The literature summary of Santos et al. (1998) indicated that, except for soybean meal, treating dietary proteins to increase RUP did not improve milk or protein yield in lactating cows; these results can be attributed to both reduced intestinal digestibility and relatively poor AA pattern of the RUP sources.

Calsamiglia and Stern (1995) developed a "3-step" approach to quantify intestinal digestibility of feed proteins escaping the rumen. This approach substitutes for the in situ mobile bag technique (NRC, 2001). The assay is based on collecting $\mathrm{N}$ residues after 16 -h ruminal in situ incubations, assuming this is equivalent to the fraction of protein that would escape the rumen at a passage rate of $6 \%$ per hour, and incubating the residues sequentially with pepsin and pancreatin as a proxy for abomasal and small intestinal digestion. Because both degradation rate and passage rate influence the fraction escaping the rumen, in situ incubation times should be adjusted down from $16 \mathrm{~h}$ to obtain a residue equivalent to actual RUP. This approach has been modified (Gargallo et al., 2006) and widely adopted. Boucher et al. (2009) found that pepsin-pancreatin digestibility of total AA from in situ residues was highly correlated with total AA digestibility in cecectomized roosters. Others have used pepsin-pancreatin to assess digestion in the acid stomach and intestines (e.g., Akeson and Stahmann, 1964; Craig and Broderick, 1981).

\section{Utilization of Protein in Forages}

Dairy farmers have always been proud of their highquality forages, particularly legume silages that contain high concentrations of CP. The winning alfalfa silage at the Forage Super Bowl at the World Dairy Expo 
usually contains 26 to $28 \% \mathrm{CP}$ on a DM basis. Alfalfa breeders have been selecting for high $\mathrm{CP}$ content for several decades and the result is apparent in how alfalfa composition has changed over the years. Alfalfa hay "all analyses" was reported by Henry and Morrison (1917) to have (DM basis) 16.3\% CP, whereas legume hay "all samples" is now reported to have $20.2 \%$ CP (NRC, 2001). The alfalfa silage fed in the last 5 trials published from work at the US Dairy Forage Center (Wisconsin) ranged from 21.0 to $26.4 \%$, averaging $22.9 \% \mathrm{CP}$ (DM basis). The proportion of NPN in these silages averaged $54 \%$ of the $\mathrm{CP}$ equivalent, necessitating incorporation of corn silage into the diet to dilute out the $\mathrm{CP}$ and provide fermentable energy to utilize this NPN.

The recognition that there were major problems with utilization of forage $\mathrm{CP}$, especially in hay-crop silages, originated with work in the United Kingdom. Kemble (1956) ensiled ryegrass forage and studied the changes in the $\mathrm{N}$ constituents over time, observing that soluble $\mathrm{N}$ accounted for 54 to $64 \%$ of total $\mathrm{N}$ within $7 \mathrm{~d}$ of ensiling; about one-third of the soluble $\mathrm{N}$ was free $\alpha$-amino N. Silage made from ensiling "microorganism-free" forage contained $60 \%$ soluble $\mathrm{N}$ after $16 \mathrm{~d}$, indicating that plant, rather than microbial, proteases broke the protein down in the silo. McKersie (1981) characterized the proteases in alfalfa plant tissue, noting that activities were maximal at 40 to $50^{\circ} \mathrm{C}$. Increasing the rate of $\mathrm{pH}$ drop in the silo reduces proteolysis, preserving more intact protein; however, proteolysis in the silo continues even at an "ideal" silage $\mathrm{pH}$ of 4.0 , albeit at only about $25 \%$ of the rate at pH 6.0 (McKersie, 1985). The decrease in $\mathrm{pH}$ in the silage mass is hastened by carbohydrate fermentation and hay-crop silages typically have low amounts of fermentable carbohydrates (McDonald et al., 1991).

Formic acid application, which immediately decreases silage $\mathrm{pH}$, reduced free AA release during ensiling of 3 legumes by an average of $64 \%$ (McKersie, 1985). Although less common now, treating forages with formic acid at ensiling was widely applied in Europe as a means of preserving more protein in direct-cut silages. However, positive effects of formic acid treatment were also found with wilted alfalfa silage (Nagel and Broderick, 1992).

Wilting forage to increase DM content at ensiling reduces the rate of proteolysis in the silo (Muck, 1987; McKersie and Buchanan-Smith, 1982). Charmley and Veira (1990) observed that mild heat treatment reduced proteolytic activity in direct-cut alfalfa by twothirds and increased intact protein in silage at feed-out from 34 to $61 \%$ of total CP. Feeding this heat-treated silage increased NAN, total AA, and EAA flow to the intestine in sheep. Although lower in total CP due to leaf loss at harvest, feeding alfalfa as dry hay resulted in improved milk and protein yields and $\mathrm{N}$ efficiency versus feeding alfalfa harvested as silage from alternate windrows in the same fields (Broderick, 1995). McDonald et al. (1991) described in detail the factors that influence NPN formation when forage crops are ensiled. Muck (1988) enumerated useful management strategies for improving utilization of silage $\mathrm{CP}$ by lactating cows.

Pichard et al. (2006) quantified the protein degradation activity in a large array of forage species, observing relative proteolytic index values ranging from 0.12 to 0.77 units; highest proteolytic activities, ranging from 0.44 to 0.77 were observed in Medicago species, with the highest value for Medicago sativa (common alfalfa). This suggested that forage crops might be selected for lower NPN formation in the silo. In fact, red clover (Trifolium pratense) yields lower NPN silage because it has a polyphenol oxidase enzyme system that forms $o$-quinones from endogenous plant $o$-diphenols, compounds that react with foliage proteins to reduce their breakdown both in the silo and rumen (Fijałkowska et al., 2015). Papadopoulos and McKersie (1983) observed that red clover silage had about half the NPN content of alfalfa, bird's-foot trefoil, bromegrass, and orchardgrass silages. Although red clover silage was lower in total $\mathrm{CP}$, replacing alfalfa silage with red clover silage reduced concentrations of ruminal ammonia and MUN and improved $\mathrm{N}$ efficiency without reducing milk and protein yield in lactating cows (Broderick, 2002).

The value of condensed tannins for improving efficiency of $\mathrm{N}$ utilization in ruminants was first recognized in trials conducted in Australia and New Zealand. An example were the findings of Barry et al. (1986), who observed more than a doubling of $\mathrm{N}$ retention in sheep fed fresh forage as bigfoot trefoil (Lotus pedunculatus) versus trefoil treated with polyethylene glycol to inactivate the ruminal effects of the condensed tannins. A related species, birdsfoot trefoil (Lotus corniculatus) with lower levels of condensed tannin, yielded silage with NPN content similar to that of red clover silage (Albrecht and Muck, 1991). The condensed tannins in birdsfoot trefoil also reduced protein degradation in the rumen (Broderick and Albrecht, 1997) and, compared with alfalfa, grazing this forage increased weight gain and intestinal sulfur-AA absorption in to sheep (Waghorn, 2008). Greater milk yield and N efficiency and reduced milk urea and urinary $\mathrm{N}$ excretion were observed when birdsfoot trefoil silage replaced alfalfa silage in 3 lactation studies (Hymes-Fecht et al., 2013; Broderick et al., 2017). Misselbrook et al. (2005) observed reduced losses of volatile $\mathrm{N}$ from manure produced by cows fed birdsfoot trefoil in one of these trials. Efforts have been successful at inserting the polyphenol oxidase enzyme system into alfalfa (Sullivan et al., 2008), although work is continuing to enable the plant to produce en- 
dogenous o-diphenol substrates (Sullivan and Zeller, 2013). Genetic engineering is also underway to extend condensed tannin expression from the seed coat to the herbage in alfalfa (Li et al., 2016).

Utilization of proteins in grazed forages is inefficient because ruminal degradation of protein in fresh forages is comparable to that of silage CP (Hoffman et al., 1999) and because of relatively low concentrations of fermentable carbohydrates (Bargo et al., 2003). Moreover, some workers have speculated that plant proteases are released into the rumen with cell rupture of forage tissues, due to rumination and the anaerobic environment of the rumen, augmenting microbial protein degradation (Pichard et al., 2006). Roche et al. (2017) have reviewed pasture-based feeding and management of dairy cows in another paper in this issue.

\section{Early Recognition of Importance of AA}

Not until the discovery of threonine (Thr; the last of the 20 protein AA to be identified) and the undisputed evidence that Thr was a dietary essential AA, both occurring in the laboratory of W. C. Rose (McCoy et al., 1935), could serious consideration be given to establishing AA requirements for animals. However, it was not until the work of the "Davis Tracer Team" that the absolute essentiality of the same AA was confirmed for dairy cows. In one such experiment, ${ }^{14} \mathrm{C}$-labeled carbonate and the 3 major VFA were injected into the blood of lactating cows and the labeling pattern determined in milk AA (Black et al., 1952). The presumption was that only NEAA would contain ${ }^{14} \mathrm{C}$. The 7 NEAA analyzed were heavily labeled, whereas the 7 EAA analyzed (Thr and Trp were not determined) were labeled to only a fraction of that observed in the NEAA. It was noted that, unlike the EAA, the semi-essential AA Arg was extensively labeled, particularly when ${ }^{14} \mathrm{C}$-propionate was the precursor.

Although it was known for some time after this research that dairy cows required the same EAA as nonruminant mammals, nutritionists labored under the assumption that ruminally synthesized microbial protein plus feed protein escaping ruminal degradation covered all bases. This was likely the case when average milk production in the United States was about 2,300 $\mathrm{kg} / \mathrm{yr}$ (Reid, 1956). However, average production per cow is now more than 4 times that amount, with many herds exceeding $13,500 \mathrm{~kg}$, an almost 6-fold increase. Following on from trials conducted with sheep showing substantial wool growth responses with abomasal infusions of casein and small amounts of sulfur-AA, several similar abomasal infusion studies were conducted in the late 1960s and early 1970s with dairy cows producing 25 to $35 \mathrm{~kg} / \mathrm{d}$ of milk. Although cows in these trials were fed diets thought to be protein-adequate, milk and especially milk protein yield responses of about 12 to $13 \%$ were observed with casein infusion. Example papers from this era are those of Broderick et al. (1970), Clark et al. (1973, 1977), and Vik-Mo et al. (1974).

\section{Limiting $A A$}

Because of the lactation responses to abomasally infused casein, the obvious question in the early 1970s was whether some AA were more limiting than others. No papers in JDS provided either direct or indirect evidence to answer that question until workers at Penn State observed interesting responses to feeding the Ca-salt of methionine hydroxyl analog, now referred to as 2-hydroxy-(4-methylthio) butanoic acid (HMB). Griel et al. (1968) reported increased yield of 4\% FCM with supplementation of $40 \mathrm{~g} / \mathrm{d}$, but not $80 \mathrm{~g} / \mathrm{d}$, of Ca-HMB. This effect may have been related to yield response being expressed as FCM because this group observed stimulation of in vitro lipid synthesis by Met and increased blood serum lipids with feeding of CaHMB (Patton et al., 1970).

The first paper on feeding a rumen-protected AA was that of Broderick et al. (1970), who fed an encapsulated Met supplement to early- to mid-lactation Holstein cows in amounts that provided $0,5,15$, or $45 \mathrm{~g} / \mathrm{d}$ of Met. The basal ration, which contained $15.3 \% \mathrm{CP}$, was ad libitum urea-treated corn silage, 8 to $11.5 \mathrm{~kg} / \mathrm{d}$ of a concentrate mix (ground shelled corn, ground oats, soybean oil meal, urea, minerals, and vitamins), and $2.1 \mathrm{~kg} / \mathrm{d}$ of legume-grass hay. There was no effect of treatment on feed intake, yield of milk or milk components, or milk component percentages. Cows averaged $26 \mathrm{~kg}$ of milk per day. Based on increased plasma Met concentrations and plasma Met:Val ratios, it was clear that at least some Met from the supplement was being absorbed. Williams et al. (1970) also observed no production benefits of feeding $12 \mathrm{~g} / \mathrm{d}$ of Met from the same rumen-protected Met supplement when cows were fed a basal ration of $60 \%$ corn silage and $40 \%$ concentrate (corn, oats, dehydrated alfalfa, bran, molasses, urea, minerals, and vitamins) containing 13 to $14 \% \mathrm{CP}$. Fat-corrected milk production averaged $18.1 \mathrm{~kg} / \mathrm{d}$. In contrast to the findings of Broderick et al. (1970), Williams et al. (1970) did not observe increased plasma Met concentrations. Although there was no evidence based on production responses that Met was limiting in these experiments, Broderick et al. (1970) interpreted changes in plasma AA concentrations as evidence that Met may have been the most limiting AA in their experiment.

In contrast to feeding encapsulated Met, Fisher (1972) intravenously infused incremental amounts of 
Met $(0,11$, and $25 \mathrm{~g} / \mathrm{d})$, His $(0,21$, and $50 \mathrm{~g} / \mathrm{d})$, and Lys $(0,34$, and $66 \mathrm{~g} / \mathrm{d})$ into early-lactation Holstein cows fed a ration of corn silage, ground shelled corn, urea, minerals, and vitamins. Compared with no Met supplement, feed intake was higher with the second Met treatment $(12.5$ vs. $10.8 \mathrm{~kg} / \mathrm{d})$, which tended to increase milk yield (16.6 vs. $16.1 \mathrm{~kg} / \mathrm{d}$ ) and significantly increase milk protein yield (520 vs. $490 \mathrm{~g} / \mathrm{d}$ ). The intake and yield of milk and protein were lower on the third Met treatment.

Because of the inconsistent responses with Met observed in the aforementioned experiments, a series of 5 abomasal infusion experiments was conducted by Schwab et al. (1976) to determine the sequence of AA limitation in early- and mid-lactation cows fed cornbased rations without protein supplementation. Single $\mathrm{AA}$ and AA mixtures were infused. All rations contained alfalfa-grass hay, ground shelled corn, beet pulp, and molasses; 4 rations contained ground oats and 3 contained corn silage. Ration CP was similar at 10.7 to $11.5 \%$ of DM. Intake of DM averaged $19 \mathrm{~kg} / \mathrm{d}$ and milk yield averaged $29 \mathrm{~kg} / \mathrm{d}$. All trials were Latin square designs with 9-d periods. Results indicated that (1) milk protein content was more sensitive than protein yield as a response criterion to AA infusions; (2) Met alone had no effect on production measurements; (3) Lys alone resulted in $16 \%$ of the milk protein yield response obtained with sodium caseinate, whereas Lys and Met together accounted for $43 \%$ of that milk protein response; (4) little change occurred in plasma concentrations of other AA when Lys and Met were infused together; and (5) the response in content and yield of milk protein with the 10 EAA was of the same magnitude as that with sodium caseinate, indicating that NEAA were not limiting. Based on the AA composition of common protein supplements compared with ruminally synthesized microbial protein, the authors concluded that Lys and Met would likely be the most limiting AA for lactating cows fed corn-based rations and that ingredient composition of the ration would influence which AA were most limiting.

Numerous experiments since then have identified Met and Lys most frequently as the 2 most limiting AA for lactating dairy cows fed corn-based rations (NRC, 2001). Research conducted since the publication of NRC (2001) has confirmed these findings (e.g., Noftsger and St-Pierre, 2003; Socha et al., 2005; St-Pierre and Sylvester, 2005; Ordway et al., 2009; Appuhamy et al., 2011; Chen et al., 2011; Lee et al., 2012; Osorio et al., 2013; Giallongo et al., 2016; Zhou et al., 2016b). That Met and Lys have been implicated as limiting AA in many different feeding situations should not be surprising given their low concentrations in most feed proteins relative to concentrations in rumen bacteria, milk, and tissue protein.

Other researchers have shown that His is likely the first-limiting AA in lactating dairy cows fed high-forage grass silage-based diets supplemented with barley and oats, with or without feather meal as a sole or primary source of supplemental RUP (e.g., Kim et al., 1999, 2000, 2001; Vanhatalo et al., 1999; Korhonen et al., 2000; Huhtanen et al., 2002). Histidine has also been shown to be a potential limiting AA after Lys and Met when cows are fed low CP (MP-deficient) diets based on corn silage and alfalfa haylage (Lee et al., 2012; Giallongo et al., 2016). Again, these findings should not be surprising given the low content of His in barley and oats compared with corn, the low content of His in feather meal compared with other protein supplements, and the low content of His in rumen-synthesized bacteria and protozoa compared with milk (NRC, 2001; Sok et al., 2017).

\section{Benefits of Balancing for Limiting AA}

The benefits of balancing for more adequate amounts of limiting AA in MP on production, particularly milk protein production, and potential sparing of RUP have been understood for many years. As expected and noted in the aforementioned experiments, responses are variable.

Recent research indicates that transition cows may benefit the most from balancing for limiting AA. For example, supplementing high-Lys diets with rumen-protected Met not only resulted in significant increases in DMI, milk yield, and milk protein concentrations (Osorio et al., 2013; Zhou et al., 2016b) but measurements of liver function, inflammation, and oxidative stress also revealed improved immuno-metabolic status (Osorio et al., 2014; Zhou et al., 2016a). These studies not only underscore the importance of Met as a limiting AA for protein synthesis in many diets, but highlight its need for the synthesis of the sulfur-containing antioxidants (glutathione and taurine) and its key role in one-carbon metabolism where hundreds of methylation reactions acquire methyl groups from it (Ulrey et al., 2005).

The effect of improved Lys and Met nutrition of the transition cow also appears to extend beyond the production and health benefits realized by the cow. For example, maternal Met supplementation has been shown to affect gene expression (Peñagaricano et al., 2013) and lipid content of preimplantation embryos (Acosta et al., 2016) and to alter the mRNA abundance of 1-carbon, Met, and transulfuration (involved in the synthesis of glutathione and taurine) pathways in the liver of the newborn calves (Jacometo et al., 2016). 


\section{Rumen-Protected AA}

It has long been understood that ruminally protected forms of the most limiting AA would be needed for AA balancing. Attempts to develop rumen-protected Met supplements began in the 1960s when Met was first observed to be the first-limiting AA in sheep and indirect evidence indicated it might be first limiting in lactating dairy cows. Early products included Met supplements such as those produced by Sibbald et al. (1968) (marketed by Delmar Chemicals, LaSalle, QC, Canada) and a product called Ketionin that was developed in the 1970s and marketed by Rumen Kjemi A/S (Oslo, Norway). The Delmar product consisted of a core of $20 \%$ DL-Met, colloidal kaolin, and tristearin wrapped in a continuous film of tristearin. Although shown to be effective (e.g., Broderick et al., 1970), it was also shown to suffer from limited intestinal digestibility (Grass and Unangst, 1972). The authors suggested that the intestinal release of Met from the product was poor and that it could be improved, without compromising ruminal protection, by replacing some of the kaolin and tristearin with $\mathrm{CaCO}_{3}$ and oleic acid. The resulting product (Ketionin) contained 30\% DL-Met, 2\% glucose, $4 \%$ flavoring, antioxidant and stabilizing agents, $6 \%$ $\mathrm{CaCO}_{3}$, and $58 \%$ fatty acids (US Patent No. 3,959,493). Daugaard (1978) concluded that $80 \%$ of the product escaped ruminal degradation and that $20 \%$ was lost in feces of lactating dairy cows. Arambel et al. (1987) reported similar findings when the Met product was fed to growing heifers: $72 \%$ escaped ruminal degradation and $19 \%$ was excreted in the feces. These encapsulated Met products, as well as others, were shown to increase plasma Met when fed to ruminants (Loerch and Oke, 1989).

These details about early efforts are provided to highlight that it has long been understood that producing products with both excellent protection from ruminal degradation and high intestinal release is not easy. Therefore, considerable effort was made in the 1980s and 1990s to find alternatives to encapsulation by screening and evaluating numerous analogs (e.g., Met hydroxy analog) and derivatives (e.g., isopropylDL-Met, tert-butyl-DL-Met, $N$-stearoyl-DL-Met and di-hydroxymethyl-L-Lys-Ca) of Met and Lys. However, because of minimal success, attention was again focused on encapsulation technologies.

It has also been known that to produce a viable rumen-protected AA supplement, product stability must be maintained when mixing with other feeds, both in the feed mill and on the farm. However, a consideration that seems to have been missed by some suppliers, particularly those that have more recently introduced products, is product stability in wet TMR. The recent study conducted at the Miner Institute (Chazy, NY), where researchers assessed Lys release from 6 different rumen-protected Lys products exposed to TMR with low or high moisture content with or without the added effects of mechanical mixing, clearly uncovered the weaknesses of some of the protection technologies (Ji et al., 2016).

The commercial production of high-quality rumenprotected AA supplements is difficult. Leaders in this business have understood this challenge for many years. As is already known, current products are far from being created equal and users should not use products that have not undergone rigorous, documented, and transparent evaluations of how much of the contained AA gets absorbed. It is apparent that achieving high quality and consistent products takes extraordinary refinements of encapsulation or protection technology.

\section{Evolution of Guidelines and Models for Protein Feeding}

Guidelines for protein feeding have evolved from simple feeding standards for dietary $\mathrm{CP}$ to complex nutrition models designed to predict supplies and requirements for rumen ammonia and peptides (or RDP) and intestinally absorbable AA. However, because of the complexity of rumen fermentation and its effect on nutrient availability to the host animal and the lack of adequate quantitative data on tissue protein and AA metabolism of the dairy animal, progress in developing nutrition models that allow for improved protein nutrition has been painfully slow. The Cornell Net Carbohydrate Protein System (O'Connor et al., 1993; Fox et al., 2004) and CPM-Dairy (Boston et al., 2000; Tedeschi et al., 2008) were the first 2 models available for balancing rations for $\mathrm{AA}$.

Perhaps the first important nutritional model that tried to account for microbial protein formation in the rumen and ruminal escape of feed protein was the urea fermentation potential (UFP) system of Burroughs et al. (1975). The UFP of the diet was computed from TDN content, an estimate of the energy available in the rumen to drive microbial protein synthesis, and RUP values were provided for several common feeds. Estimates of supply of MP and 5 metabolizable AA (Arg, Cys, His, Lys, and Met) were computed for microbial protein and feed RUP, as well as requirements for the same nutrients for maintenance, pregnancy, and lactation of the dairy cow. Although many of the numeric factors used in these computations were estimated by Burroughs and others from nonruminant data, most of the concepts are still with us. The "soil" in the field of dairy protein nutrition was already tilled and the "seeds" of the UFP model fell on fertile ground. The 
protein models and feeding philosophies appearing in the years immediately following introduction of the UFP model are summarized in the publication from a symposium held at Oklahoma State University in late 1980 (Owens, 1982).

To highlight the slowness of the development of protein models, we describe the evolution of the dairy National Research Council protein systems. In the first 5 editions of dairy NRC (beginning in 1945 and ending 1978), dietary requirements were expressed as CP. In NRC (1989), dietary requirements were expressed as CP or degraded intake CP (DIP) and undegraded intake CP (UIP), and metabolic requirements as absorbed protein. Mean values of ruminal degradability for common feeds, derived from in vivo and in situ studies using sheep and cattle, were reported. A fixed intestinal digestibility of $80 \%$ for UIP and microbial true protein was used for predicting supply of absorbed protein.

In recognition of the limitations of the NRC (1989) protein model, and because of the availability of new data, the NRC (2001) committee "started over" and developed a semi-mechanistic, semi-empirical protein and AA model. In NRC (2001), dietary requirements are expressed as RDP and RUP and metabolic requirements are expressed as MP. In contrast to NRC (1989), (1) microbial CP flows are predicted from total digestible OM intake instead of NE intake; (2) a mechanistic system is used for predicting the RDP and RUP content of feeds that recognizes that the proportional content of these 2 fractions is not constant and is affected by DMI and diet composition; (3) variable estimates of digestibility are assigned to the RUP fraction of each feed; (4) flows of endogenous protein are predicted; and (5) the profile of EAA in duodenal protein is predicted and flows of EAA and their content in MP are calculated.

The NRC committee concluded that knowledge was too limited to put forth a model that "quantified" AA requirements. However, so that advances could be made in identifying the ideal profile of EAA in MP and nutritionists could begin balancing for more optimum concentrations of EAA in MP, the protein model was extended to one that would most accurately predict the profile of EAA in duodenal protein. This was accomplished by using a multivariate regression, semimechanistic approach where the developed equations (one for each EAA) were allowed to adapt to measured data and allowed for partial correction of errors in the mechanistically determined supplies of microbial protein and RUP. Dose-response plots relating measured changes in content and yield of milk protein to modelpredicted changes in Lys and Met concentrations in MP were developed to identify their optimal concentrations.
Although the NRC (2001) model has been shown to be an improved model for protein feeding and for balancing diets for more optimal concentrations of limiting AA in MP, limitations exist and more robust and mechanistic models are needed for predicting supplies and requirements of rumen-available $\mathrm{N}$ and metabolizable AA. There are now many nutrition models describing protein and AA utilization in dairy cattle, as well as many papers evaluating these models (e.g., Schwab et al., 2005; Pacheco et al., 2006, 2012; Tedeschi et al., 2014, 2015). Tedeschi et al. (2014) concluded from their review of 6 basic nutrition models (mostly empirical systems) and 5 complex nutrition models (mostly mechanistic systems) that some of the more complex models were not suited for predicting milk production and that simpler systems might be more resilient to production conditions around the world.

Considerable research has been published in recent years that should provide important information for improving models for protein feeding. Some selected examples follow. First, a comparison of predicted digestible EAA flows with NRC (2001) and Cornell Net Carbohydrate Protein System (version 5.0.34) models with measurements of net portal absorption in lactating dairy cows, taking into account potential losses of EAA from the site of digestion to net portal absorption, indicated that the true intestinal digestibility of both the RUP and the microbial protein fractions in the NRC (2001) model should be increased (Pacheco et al., 2006). Second, most protein models still assume a constant efficiency of utilization of MP and AA for maintenance and productive functions. As might be expected, it has been demonstrated that this is not true (Arriola Apelo et al., 2014). For example, the efficiency of use of MP by dairy cows is influenced by the balance of EAA in MP (e.g., Noftsger and St-Pierre, 2003; Chen et al., 2011; Haque et al., 2012; Osorio et al., 2013). It is also known that there is a decreasing marginal efficiency of use of AA as supplies approach requirements (Doepel et al., 2004; Metcalf et al., 2008). The NorFor nutritional model (Volden, 2011), for example, incorporates variable efficiencies of use for MP and metabolizable AA. Third, a large body of research is accumulating on intermediary metabolism of AA in lactating dairy cows with a focus on quantifying the affinity of splanchnic tissues (visceral tissues including the intestines) and the mammary gland for EAA. It is clear that the affinity varies among tissues and individual EAA, and that selected EAA, energy substrates, and hormones have the potential to activate signaling pathways that in turn regulate local blood flow, tissue extraction of EAA, and rates of milk protein synthesis (Arriola Apelo et al., 2014; Curtis et al., 2014; Castro et al., 2016). These findings indicate that a more thorough understand- 
ing of the dynamics of EAA metabolism should lead to improved factorial prediction of AA requirements. And fourth, as cited earlier, there are differences in AA composition among fluid- and particle-associated bacteria and protozoa (Sok et al., 2017). By assuming $33 \%$ fluid-associated bacteria, 50\% particle-associated bacteria, and $17 \%$ protozoa in mixed microbial CP, Sok et al. (2017) stated that the resulting AA concentrations would decrease supply estimates of Met and Thr and increase supply estimates of Ile, Lys and Phe by 5 to $10 \%$ compared with the often used values of bacteria (Clark et al., 1992) in factorial models for predicting AA flows from microbial protein.

It is anticipated that protein and AA models will continue to evolve, which will allow for more accurate prediction of supplies and requirements of $\mathrm{N}$ substrates and AA for rumen microorganisms and the host animal. An excellent overview of the quantitative fates of protein and AA in dairy cows is found in Lapierre et al. (2005). Moraes and Fadel (2013) discuss the application of nutritional models to lessen the environmental footprint of livestock production. McNamara et al. (2016) discuss methodology to support model development and validation, including what information should be reported in publications to assist in this process.

\section{Milk Urea N as a Tool for Monitoring Protein Status}

It seems fitting to end this paper with mention of this topic, given the interest within the dairy industry to feed lower protein diets and increase the efficiency of conversion of dietary $\mathrm{N}$ into milk $\mathrm{N}$. Urea, as already discussed, is the main nitrogenous end product of protein metabolism and is excreted in urine. When there is an excess of $\mathrm{N}$ relative to energy in the rumen, ruminal ammonia concentration increases. Unused ruminal ammonia enters the portal blood through the rumen wall and is captured by the liver, where it is detoxified by conversion to urea. The liver also produces urea from ammonia derived from deamination of AA arising from intestinal absorption and systemic protein turnover. Urea circulates in the blood to the kidneys and is excreted with the urine. Urea also diffuses from the blood back into the rumen, flows into the rumen via saliva, or diffuses into milk, in the case of lactating females.

As a result of these metabolic transactions, BUN is highly correlated with ruminal ammonia, and MUN is highly correlated with BUN. Because of these relationships, monitoring MUN has become a useful tool for assessing whether a ration contains an over or under supply of RDP relative to energy in the rumen. Milk urea $\mathrm{N}$ has been shown to be highly correlated with urinary N excretion (Jonker et al., 1998; Kauffman and
St-Pierre, 2001) and is a good indicator of ammonia emissions from dairy manure (Burgos et al., 2007).

\section{SUMMARY AND CONCLUSIONS}

Considerable progress has been made in protein and AA nutrition of cows. Worldwide, most producers and nutritionists still consider only $\mathrm{CP}$ when evaluating protein feeds and animal requirements. However, this is changing, with a continued greater focus on protein and AA nutrition research and industry interest in feeding lower protein diets. Motives include reduced feed costs, improved efficiency of production and dietary protein use, higher production, and environmental issues. It is anticipated that these feeding management strategies will continue to be supported by research aimed at improving protein and AA requirement models, increasing efficiency of microbial protein synthesis and capturing of recycled $\mathrm{N}$, and more reliable characterization of protein and AA supplements.

\section{REFERENCES}

Acosta, D. A. V., A. C. Denicol, P. Tribulo, M. I. Rivelli, C. Skenandore, Z. Zhou, D. Luchini, M. N. Corrêa, P. J. Hansen, and F. C. Cardoso. 2016. Effects of rumen-protected methionine and choline supplementation on the preimplantation embryo in Holstein cows. Theriogenology 85:1669-1679.

Ahvenjärvi, S., A. Vanhatalo, P. Huhtanen, and T. Varvikko. 2000. Determination of reticulo-rumen and whole-stomach digestion in lactating cows by omasal canal or duodenal sampling. Br. J. Nutr. 83:67-77.

Akeson, W. R., and M. A. Stahmann. 1964. A pepsin pancreatin digest index of protein quality evaluation. J. Nutr. 83:257-261.

Albrecht, K. A., and R. E. Muck. 1991. Proteolysis in ensiled forage legumes that vary in tannin concentration. Crop Sci. 31:464-469.

Annison, E. F. 1956. Nitrogen metabolism in the sheep. Protein digestion in the rumen. Biochem. J. 64:705-714.

Appuhamy, J. A. D. R. N., J. R. Knapp, O. Becvar, J. Escobar, and M. D. Hanigan. 2011. Effects of jugular-infused lysine, methionine, and branched-chain amino acids on milk protein synthesis in highproducing dairy cows. J. Dairy Sci. 94:1952-1960.

Arambel, M. J., E. E. Bartley, J. L. Camac, S. M. Dennis, T. G. Nagaraja, and A. D. Dayton. 1987. Rumen degradability and intestinal availability of a protected methionine product and its effects on rumen fermentation, and passage rate of nutrients. Nutr. Rep. Int. 35:661-672.

Arambel, M. J., and C. N. Coon. 1981. Effect of dietary protein on amino acids and microbial protein of duodenal digesta. J. Dairy Sci. 64:2201-2208.

Armentano, L. E., and R. W. Russell. 1985. Method for calculating digesta flow and apparent absorption of nutrients from nonrepresentative samples of digesta. J. Dairy Sci. 68:3067-3070.

Arriola Apelo, S. I., J. R. Knapp, and M. D. Hanigan. 2014. Invited review: Current representation and future trends of predicting amino acid utilization in the lactating dairy cow. J. Dairy Sci. 97:4000-4017.

Bach, A., S. Calsamiglia, and M. D. Stern. 2005. Nitrogen metabolism in the rumen. J. Dairy Sci. 88(E. Suppl.):E9-E21.

Bargo, F., L. D. Muller, E. S. Kolver, and J. E. Delahoy. 2003. Production and digestion of supplemented dairy cows on pasture. J. Dairy Sci. 86:1-42.

Barry, T. N., T. R. Manley, and S. J. Duncan. 1986. The role of condensed tannins in the nutritional value of Lotus pedunculatus for 
sheep. 4. Sites of carbohydrate and protein digestion as influenced by dietary reactive tannin concentrations. Br. J. Nutr. 55:123-137.

Black, A. L., M. Kleiber, and A. H. Smith. 1952. Carbonate and fatty acids as precursors of amino acids in casein. J. Biol. Chem. 197:365-370.

Boston, R. C., D. G. Fox, C. J. Sniffen, R. Janczewski, R. Munsen, and W. Chalupa. 2000. The conversion of a scientific model describing dairy cow nutrition and production to an industry tool: The CPM Dairy project. Pages 361-377. In: Modelling Nutrient Utilization in Farm Animals. J. P. McNamara, J. France, and D. Beever, ed. CABI Publishing, Oxford, UK.

Boucher, S. E., S. Calsamiglia, C. M. Parsons, H. H. Stein, M. D. Stern, P. S. Erickson, P. L. Utterback, and C. G. Schwab. 2009 Intestinal digestibility of amino acids in rumen undegradable protein estimated using a precision-fed cecectomized rooster bioassay: I. Soybean meal and Soyplus. J. Dairy Sci. 92:4489-4498.

Broderick, G. A. 1987. Determination of protein degradation rates using a rumen in vitro system containing inhibitors of microbial nitrogen metabolism. Br. J. Nutr. 58:463-475.

Broderick, G. A. 1995. Performance of lactating dairy cows fed either alfalfa silage or alfalfa hay as the sole forage. J. Dairy Sci. 78:320-329.

Broderick, G. A. 2002. An analysis of the relative value of lucerne and red clover silages for lactating cows. Pages 128-129 in Proc. XIIIth Int. Silage Conf., Auchincruive, Scotland. L. M. Gechie and C. Thomas, ed. Scottish Agricultural College, Ayr, UK.

Broderick, G. A., and K. A. Albrecht. 1997. Ruminal in vitro degradation of protein in tannin-free and tannin- containing forage legume species. Crop Sci. 37:1884-1891.

Broderick, G. A., and S. Colombini. 2010. In vitro methods to determine rate and extent of ruminal protein degradation. Pages 691-702 in Energy and Protein Metabolism and Nutrition. EAAP Publication No. 127. G. M. Crovetto, ed. Wageningen Academic Publishers, Wageningen, the Netherlands.

Broderick, G. A., S. Colombini, S. Costa, M. A. Karsli, and A. P. Faciola. 2016. Chemical and ruminal in vitro evaluation of Canadian canola meals produced over 4 years. J. Dairy Sci. 99:7956-7970.

Broderick, G. A., A. P. Faciola, and L. E. Armentano. 2015. Replacing dietary soybean meal with canola meal improves production and efficiency of lactating dairy cows. J. Dairy Sci. 98:5672-5687.

Broderick, G. A., J. H. Grabber, R. E. Muck, and U. C. Hymes-Fecht. 2017. Replacing alfalfa silage with tannin-containing birdsfoot trefoil silage in total mixed rations for lactating dairy cows. J. Dairy Sci. 100:3548-3562. https://doi.org/10.3168/jds.2016-12073.

Broderick, G. A., P. Huhtanen, S. Ahvenjärvi, S. M. Reynal, and K. J. Shingfield. 2010. Quantifying ruminal nitrogen metabolism using the omasal sampling technique in cattle-A meta-analysis. J. Dairy Sci. 93:3216-3230.

Broderick, G. A., T. Kowalczyk, and L. D. Satter. 1970. Milk production response to supplementation with encapsulated methionine per os or casein per abomasum. J. Dairy Sci. 53:1714-1721.

Broderick, G. A., and N. R. Merchen. 1992. Markers for quantifying microbial protein synthesis in the rumen. J. Dairy Sci. 75:26182632 .

Broderick, G. A., D. B. Ricker, and L. S. Driver. 1990. Expeller soybean meal and corn by-products versus solvent soybean meal for lactating dairy cows. J. Dairy Sci. 73:453-462.

Burgos, S. A., J. G. Fadel, and E. J. DePeters. 2007. Prediction of ammonia emission from dairy cattle manure based on milk urea nitrogen: relation of milk urea nitrogen to urine urea nitrogen excretion. J. Dairy Sci. 90:5499-5508.

Burroughs, W., D. K. Nelson, and D. R. Mertens. 1975. Evaluation of protein nutrition by metabolizable protein and urea fermentation potential. J. Dairy Sci. 58:611-619.

Calsamiglia, S., A. Ferret, C. K. Reynolds, N. B. Kristensen, and A. M. Van Vuuren. 2010. Strategies for optimizing nitrogen use by ruminants. Animal 4:1184-1196.

Calsamiglia, S., and M. D. Stern. 1995. A three-step procedure for estimating intestinal digestion of protein in ruminants. J. Anim. Sci. 73:1459-1465.
Castro, J. J., S. I. Arriola Apelo, J. A. D. R. N. Appuhamy, and M. D. Hanigan. 2016. Development of a model describing regulation of casein synthesis by the mammary target of rapamycin (mTOR) signaling pathway in response to insulin, amino acids, and acetate. J. Dairy Sci. 99:6714-6736.

Chalmers, M. I., D. F. Cuthbertson, and R. L. M. Synge. 1954. Ruminal ammonia formation in relation to the protein requirement of sheep. 1. Duodenal administration and heat processing as factors influencing fate of casein supplements. J. Agric. Sci. (Camb.) 44:254-262.

Charmley, E., and D. M. Veira. 1990. Inhibition of proteolysis in alfalfa silages using heat at harvest: Effects on digestion in the rumen, voluntary intake and animal performance. J. Anim. Sci. 68:20422051.

Chen, Z. H., G. A. Broderick, N. D. Luchini, B. K. Sloan, and E. Devillard. 2011. Effect of feeding different sources of rumen-protected methionine on milk production and N-utilization in lactating dairy cows. J. Dairy Sci. 94:1978-1988.

Clark, J. H., T. H. Klusmeyer, and M. R. Cameron. 1992. Microbial protein synthesis and flows of nitrogen fractions to the duodenum of dairy cows. J. Dairy Sci. 75:2304-2323.

Clark, J. H., H. R. Spires, and R. G. Derrig. 1973. Postruminal infusion of glucose and Na-caseinate in lactating cows. J. Anim. Sci. 37:631-644.

Clark, J. H., H. R. Spires, R. G. Derrig, and M. R. Bennink. 1977. Milk-production, nitrogen-utilization and glucose synthesis in lactating cows infused post-ruminally with sodium caseinate and glucose. J. Nutr. 107:631-644.

Coblentz, W. K., I. E. O. Abdelgadir, R. C. Cochran, J. O. Fritz, W. H. Fick, K. C. Olson, and J. E. Turner. 1999. Degradability of forage proteins by in situ and in vitro enzymatic methods. J. Dairy Sci. 82:343-354

Cocimano, M. R., and R. A. Leng. 1967. Metabolism of urea in sheep. Br. J. Nutr. 21:353-371.

Colombini, S., G. A. Broderick, and M. K. Clayton. 2011. Effect of quantifying peptide release on ruminal protein degradation determined using the inhibitor in vitro system. J. Dairy Sci. 94:19671977.

Craig, W. M., and G. A. Broderick. 1981. Effect of heat-treatment on true digestibility, in vitro digestibility and available lysine content of cottonseed meal protein. J. Anim. Sci. 52:292-301.

Crawford, R. J. Jr., W. H. Hoover, C. J. Sniffen, and B. A. Crooker. 1978. Degradation of feedstuff nitrogen in the rumen vs. nitrogen solubility in three solvents. J. Anim. Sci. 46:1768-1775.

Crooker, B. A.. C. J. Sniffen, W. H. Hoover, and L. L. Johnson. 1978. Solvents for soluble nitrogen measurements in feedstuffs. J. Dairy Sci. 61:437-447.

Curtis, R. V., J. J. M. Kim, D. L. Bajramaj, J. Doelman, V. R. Osborne, and J. P. Cant. 2014. Decline in mammary translational capacity during intravenous glucose infusion into lactating dairy cows. J. Dairy Sci. 97:430-438.

Daugaard, J. 1978. Investigation on methionine supplement to lactating cows. PhD Thesis. The Royal Veterinary and Agricultural University, Copenhagen, Denmark.

Doepel, L., D. Pacheco, J. J. Kennelly, M. D. Hanigan, I. F. Lopez, and H. Lapierre. 2004. Milk protein synthesis as a function of amino acid supply. J. Dairy Sci. 87:1279-1297.

Edmunds, B., K.-H. Suedekum, H. Spiekers, and F. J. Schwarz. 2012. Estimating ruminal crude protein degradation of forages using in situ and in vitro techniques. Anim. Feed Sci. Technol. 175:95-105.

Erdman, R. A., G. H. Proctor, and J. H. Vandersall. 1986. Effect of rumen ammonia concentration on in situ rate and extent of digestion of feedstuffs. J. Dairy Sci. 69:2312-2320.

Faldet, M. A., and L. D. Satter. 1991. Feeding heat-treated full fat soybeans to cows in early lactation. J. Dairy Sci. 74:3047-3054.

Ferguson, K. A. 1959. Influence of dietary protein percent on growth of wool. Nature 184(Suppl. 12):907.

Ferguson, K. A., J. A. Hemsley, and P. J. Reis. 1967. Nutrition and wool growth. The effect of protecting dietary protein from microbial degradation in the rumen. Aust. J. Sci. 30:215-217. 
Fijałkowska, M., B. Pysera, K. Lipiński, and D. Strusińska. 2015. Changes of nitrogen compounds during ensiling of high protein herbages-A review. Ann. Anim. Sci. 15:289-305.

Fisher, L. J. 1972. Response of lactating cows to the intravenous infusion of amino acids. Can. J. Anim. Sci. 52:377-384.

Fox, D. G., L. O. Tedeschi, T. P. Tylutki, J. B. Russell, M. E. Van Amburgh, L. E. Chase, A. N. Pell, and T. R. Overton. 2004. The Cornell Net Carbohydrate and Protein System model for evaluating herd nutrition and nutrient excretion. Anim. Feed Sci. Technol. 112:29-78.

France, J., and R. C. Siddons. 1986. Determination of digesta flow by continuous marker infusion. J. Theor. Biol. 121:105-119.

Gargallo, S., S. Calsamiglia, and A. Ferret. 2006. Technical note: A modified three-step in vitro procedure to determine intestinal digestion of proteins. J. Anim. Sci. 84:2163-2167.

Giallongo, F., M. T. Harper, J. Oh, J. C. Lopes, H. Lapierre, R. A. Patton, C. Parys, I. Shinzato, and A. N. Hristov. 2016. Effects of rumen-protected methionine, lysine, and histidine on lactation performance of dairy cows. J. Dairy Sci. 99:4437-4452.

Giallongo, F., A. N. Hristov, J. Oh, T. Frederick, H. Weeks, J. Werner, H. Lapierre, R. A. Patton, A. Gehman, and C. Parys. 2015. Effects of slow-release urea and rumen-protected methionine and histidine on performance of dairy cows. J. Dairy Sci. 98:3292-3308.

Grass, G. M., and R. R. Unangst. 1972. Glycerol tristearate and higher fatty acid mixtures for improving digestive absorption. Smith Kline French Lab, assignee. U.S. patent 3,655,864.

Griel, L. C., Jr., R. A. Patton, R. D. McCarthy, and P. T. Chandler. 1968. Milk production response to feeding methionine hydroxy analog to lactating dairy cows. J. Dairy Sci. 51:1866-1872.

Haque, M. N., H. Rulquin, A. Andrade, P. Faverdin, J. L. Peyraud, and S. Lemosquet. 2012. Milk protein synthesis in response to the provision of an "ideal" amino acid profile at 2 levels of metabolizable protein supply in dairy cows. J. Dairy Sci. 95:5876-5887.

Hart, E. B., G. Bohstedt, H. J. Deobald, and M. I. Wegner. 1939. The utilization of simple nitrogenous compounds such as urea and ammonium bicarbonate by growing calves. J. Dairy Sci. 22:785-798.

Helmer, L. G., and E. E. Bartley. 1971. Progress in the utilization of urea as a protein replacer for ruminants. A review. J. Dairy Sci. $54: 25-51$.

Henry, W. A., and F. B. Morrison. 1917. Feeds and Feeding. 17th ed. The Henry-Morrison Publishing Co., Madison, WI.

Hoffman, P. C., N. M. Brehm, D. K. Combs, L. M. Bauman, J. B. Peters, and D. J. Undersander. 1999. Predicting the effect of proteolysis on ruminal crude protein degradation of legume and grass silages using near-infrared reflectance spectroscopy. J. Dairy Sci. 82:756-763.

Hogan, J. P., and R. H. Weston. 1967. The digestion of two diets of differing protein content but with similar capacities to sustain wool growth. Aust. J. Agric. Res. 18:973-981.

Holter, J. B., N. F. Colovos, and W. E. Urban Jr.. 1968. Urea for lactating dairy cattle. IV. Effect of urea versus no urea in the concentrate on production performance in a high-producing herd. J. Dairy Sci. 51:1403-1408.

Houpt, T. R. 1959. Utilization of blood urea in ruminants. Am. J. Physiol. 197:115-120.

Huber, J. T. 1975. Protein and non-protein nitrogen-utilization in practical dairy rations. J. Anim. Sci. 41:954-961.

Huhtanen, P., P. G. Brotz, and L. D. Satter. 1997. Omasal sampling technique for assessing fermentative digestion in the forestomach of dairy cows. J. Anim. Sci. 75:1380-1392.

Huhtanen, P., V. Vanhatalo, and T. Varvikko. 2002. Effects of abomasal infusions of histidine, glucose, and leucine on milk production and plasma metabolites of dairy cows fed grass silage diets. J. Dairy Sci. 85:204-216.

Hymes-Fecht, U. C., G. A. Broderick, R. E. Muck, and J. H. Grabber. 2013. Replacing alfalfa or red clover silage with birdsfoot trefoil silage in total mixed rations increases production of lactating dairy cows. J. Dairy Sci. 96:460-469.

Ipharraguerre, I. R., J. H. Clark, and D. E. Freeman. 2005a. Rumen fermentation and intestinal supply of nutrients in dairy cows fed rumen-protected soy products. J. Dairy Sci. 88:2879-2892.
Ipharraguerre, I. R., J. H. Clark, and D. E. Freeman. 2005b. Varying protein and starch in the diet of dairy cows. I. Effects on ruminal fermentation and intestinal supply of nutrients. J. Dairy Sci. $88: 2537-2555$.

Jacometo, C. B., Z. Zhou, D. Luchini, E. Trevisi, M. N. Correa, and J. J. Loor. 2016. Maternal rumen-protected methionine supplementation and its effect on blood and liver biomarkers of energy metabolism, inflammation, and oxidative stress in neonatal Holstein calves. J. Dairy Sci. 99:6753-6763.

Ji, P., H. A. Tucker, R. E. Clark, M. Miura, and C. S. Ballard. 2016. Short communication: Effect of on-farm feeding practices on rumen protected lysine products. J. Dairy Sci. 99:1242-1246.

Jonker, J. S., R. A. Kohn, and R. A. Erdman. 1998. Using milk urea nitrogen to predict nitrogen excretion and utilization efficiency in lactating dairy cows. J. Dairy Sci. 81:2681-2692.

Karlsson, L., M. Hetta, P. Udén, and K. Martinsson. 2009. New methodology for estimating rumen protein degradation using the in vitro gas production technique. Anim. Feed Sci. Technol. 153:193202.

Kauffman, A. J., and N. R. St-Pierre. 2001. The relationship of milk urea nitrogen to urine nitrogen excretion in Holstein and Jersey cows. J. Dairy Sci. 84:2284-2294.

Kemble, A. R. 1956. Studies on the nitrogen metabolism of the ensilage process. J. Sci. Food Agric. 7:125-130.

Kim, C. H., T. G. Kim, J. J. Choung, and D. G. Chamberlain. 1999. Determination of the first limiting amino acid for milk production in dairy cows consuming a diet of grass silage and a cereal-based supplement containing feather meal. J. Sci. Food Agric. 79:17031708.

Kim, C. H., T. G. Kim, J. J. Choung, and D. G. Chamberlain. 2000. Variability in the ranking of the three most-limiting amino acids for milk protein production in dairy cows consuming grass silage and a cereal-based supplement containing feather meal. J. Sci. Food Agric. 80:1386-1392.

Kim, C. H., T. G. Kim, J. J. Choung, and D. G. Chamberlain. 2001. Effects of intravenous infusion of amino acids and glucose on the yield and concentration of milk protein in dairy cows. J. Dairy Res. 68:27-34.

Korhonen, M., A. Vanhatalo, T. Varvikko, and P. Huhtanen. 2000. Responses to graded doses of histidine in dairy cows fed grass silage diets. J. Dairy Sci. 83:2596-2608.

Krishnamoorthy, U., C. J. Sniffen, M. D. Stern, and P. J. Van Soest. 1983. Evaluation of a mathematical model of rumen digestion and an in vitro simulation of rumen proteolysis to estimate the rumenundegraded nitrogen content of feedstuffs. Br. J. Nutr. 50:555-568.

Krizsan, S. J., S. Ahvenjärvi, H. Volden, and G. A. Broderick. 2010. Estimation of rumen outflow in dairy cows fed grass silage-based diets by use of reticular sampling as an alternative to sampling from the omasal canal. J. Dairy Sci. 93:1138-1147.

Lapierre, H., R. Berthiaume, G. Raggio, M. C. Thivierge, L. Doepel, D. Pacheco, P. Dubreuil, and G. E. Lobley. 2005. The route of absorbed nitrogen into milk protein. Anim. Sci. 80:10-22.

Lapierre, H., and G. E. Lobley. 2001. Nitrogen recycling in the ruminant: A review. J. Dairy Sci. 84(E. Suppl.):E223-E236.

Lee, C., A. N. Hristov, T. W. Cassidy, K. S. Heyler, H. Lapierre, G. A. Varga, M. J. de Veth, and R. A. Patton. 2012. Rumen-protected lysine, methionine, and histidine increase milk protein yield in dairy cows fed a metabolizable protein-deficient diet. J. Dairy Sci. 95:6042-6056.

Li, P., Q. Dong, S. Ge, X. He, J. Verdier, D. Li, and J. Zhao. 2016. Metabolic engineering of proanthocyanidin production by repressing the isoflavone pathways and redirecting anthocyanidin precursor flux in legume. Plant Biotechnol. J. 14:1604-1618.

Loerch, S. C., and B. O. Oke. 1989. Rumen protected amino acids in ruminant nutrition. Pages 187-200 in Absorption and Utilization of Amino Acids. Vol. III. M. Friedman, ed. CRC Press, Boca Raton, FL.

Loosli, J. K., H. H. Williams, W. E. Thomas, F. H. Ferris, and L. A. Maynard. 1949. Synthesis of amino acids in the rumen. Science 110:144-145. 
Madsen, J., and T. Hvelplund. 1994. Prediction of in situ protein degradability in the rumen: Results of a European ringtest. Livest. Prod. Sci. 39:201-212.

Mahadevan, S., J. D. Erfle, and F. D. Sauer. 1980. Degradation of soluble and insoluble proteins by Bacteroides amylophilus protease and by rumen microorganisms. J. Anim. Sci. 50:723-728.

Mahadevan, S., J. D. Erfle, and F. D. Sauer. 1987. Preparation of protease from mixed rumen microorganisms and its use for the in vitro determination of the degradability of true protein in feedstuffs. Can. J. Anim. Sci. 67:55-64.

Mathis, C. P., R. C. Cochran, E. S. Vanzant, I. E. O. Abdelgadir, J. S. Heldt, K. C. Olson, D. E. Johnson, J. Caton, D. Faulkner, G. Horn, S. Paisley, R. Mass, K. Moore, and J. Halgerson. 2001. A collaborative study comparing an in situ protocol with single timepoint enzyme assays for estimating ruminal protein degradability of different forages. Anim. Feed Sci. Technol. 93:31-42.

McCandlish, A. C. 1920. A modification of the Haecker and Savage feeding standards for dairy cattle. J. Dairy Sci. 3:190-193.

McCandlish, A. C., and E. Weaver. 1922. Coconut meal, gluten feed, peanut meal and soybean meal as protein supplements for dairy cows. J. Dairy Sci. 5:27-39.

McCoy, R. H., C. E. Meyer, and W. C. Rose. 1935. Feeding experiments with mixtures of highly purified amino acids. VIII. Isolation and identification of a new essential amino acid. J. Biol. Chem. 112:283-302.

McDonald, I. W. 1952. The role of ammonia in ruminal digestion of protein. Biochem. J. 51:86-90.

McDonald, I. W., and R. J. Hall. 1954. The conversion of casein into microbial proteins in the rumen. Biochem. J. 67:400-405.

McDonald, P., A. R. Henderson, and S. J. E. Heron. 1991. The Biochemistry of Silage. 2nd ed. Chalcombe Publications, Kingston, UK.

McKersie, B. D. 1981. Proteinases and peptidases of alfalfa herbage. Can. J. Plant Sci. 61:53-59.

McKersie, B. D. 1985. Effect of $\mathrm{pH}$ on proteolysis in ensiled legume forage. Agron. J. 77:81-86.

McKersie, B. D., and J. Buchanan-Smith. 1982. Changes in the levels of proteolytic-enzymes in ensiled alfalfa forage. Can. J. Anim. Sci. 62:111-116.

McNamara, J. P., M. D. Hanigan, and R. R. White. 2016. Invited review: Experimental design, data reporting, and sharing in support of animal systems modeling research. J. Dairy Sci. 99:9355-9371.

Metcalf, J. A., R. J. Mansbridge, J. S. Blake, J. D. Oldham, and J. R. Newbold. 2008. The efficiency of conversion of metabolisable protein into milk true protein over a range of metabolisable protein intakes. Animal 2:1193-1202.

Miraz, M. A., and E. L. Miller. 2005. In vitro degradability of feed proteins in the rumen: Use of non-rumen proteases. Aust. J. Agric. Res. 56:797-801.

Misselbrook, T. H., J. M. Powell, G. A. Broderick, and J. H. Grabber. 2005. Dietary manipulation in dairy cattle: Laboratory experiments to assess the influence on ammonia emissions. J. Dairy Sci. 88:1765-1777.

Moraes, L. E., and J. G. Fadel. 2013. Minimizing environmental impacts of livestock production using diet optimization models. Pages 67-82 in Sustainable Animal Agriculture. E. Kebreab, ed. CABI, Boston, MA

Muck, R. E. 1987. Dry matter level effects on alfalfa silage quality: I. Nitrogen transformations. Trans. ASAE 23:170-172.

Muck, R. E. 1988. Factors influencing silage quality and their implications for management. J. Dairy Sci. 71:2992-3002.

Nagel, S. A., and G. A. Broderick. 1992. Effect of formic acid or formaldehyde treatment of alfalfa silage on nutrient utilization by dairy cows. J. Dairy Sci. 75:140-154.

Nevens, W. B. 1921a. The proteins of cottonseed meal. I. Amino acid content. J. Dairy Sci. 4:375-400.

Nevens, W. B. 1921b. The proteins of cottonseed meal. II. Nutritive value. J. Dairy Sci. 4:552-588.

Nocek, J. E., J. H. Herbein, and C. E. Polan. 1983. Total amino acid release rates of soluble and insoluble protein fractions of concen- trate feedstuffs by Streptomgces griseus. J. Dairy Sci. 66:16631667.

Noftsger, S., and N. R. St-Pierre. 2003. Supplementation of methionine and selection of highly digestible rumen undegradable protein to improve nitrogen efficiency for milk production. J. Dairy Sci. 86:958-969.

NRC. 1989. Nutrient Requirements of Dairy Cattle. 6th rev. ed. National Academy Press, Washington, DC

NRC. 2001. Nutrient Requirements of Dairy Cattle. 7th rev. ed. National Academy Press, Washington, DC.

O'Connor, J. D., C. J. Sniffen, D. G. Fox, and W. Chalupa. 1993. A net carbohydrate and protein system for evaluating cattle diets: IV. Predicting amino acid adequacy. J. Anim. Sci. 71:1298-1311.

Odle, J., and D. M. Schaefer. 1987. Influence of rumen ammonia concentration on the rumen degradation rates of barley and maize. Br. J. Nutr. 57:127-138.

Oltjen, R. R. 1969. Effects of feeding ruminants non-protein nitrogen as the only nitrogen source. J. Anim. Sci. 28:673-682.

Ordway, R. S., S. E. Boucher, N. L. Whitehouse, C. G. Schwab, and B. K. Sloan. 2009. Effects of providing two forms of supplemental methionine to periparturient Holstein dairy cows on feed intake and lactational performance. J. Dairy Sci. 92:5154-5166.

Ørskov, E. R. 1992. Protein Nutrition in Ruminants. 2nd ed. Academic Press, London, UK.

Ørskov, E. R., and I. McDonald. 1979. The estimation of protein degradability in the rumen from incubation measurements weighted according to rate of passage. J. Agric. Sci. (Camb.) 92:499-503.

Osorio, J. S., P. Ji, J. K. Drackley, D. Luchini, and J. J. Loor. 2013. Supplemental Smartamine M or MetaSmart during the transition period benefits postpartal cow performance and neutrophil function. J. Dairy Sci. 96:6248-6263.

Osorio, J. S., E. Trevisi, P. Ji, J. K. Drackley, D. Luchini, G. Bertoni, and J. J. Loor. 2014. Biomarkers of inflammation, metabolism, and oxidative stress in blood, liver, and milk reveal a better immunometabolic status in peripartal cows supplemented with Smartamine M or MetaSmart. J. Dairy Sci. 97:7437-7450.

Owens, F. N. 1982. Protein Requirements for Cattle: Proc. Int. Symp. Division of Agriculture, Oklahoma State University, Stillwater.

Pacheco, D., R. A. Patton, C. Parys, and H. Lapierre. 2012. Ability of commercially available dairy ration programs to predict duodenal flows of protein and essential amino acids in dairy cows. J. Dairy Sci. 95:937-963.

Pacheco, D., C. G. Schwab, R. Berthiaume, G. Raggio, and H. Lapierre. 2006. Comparison of net portal absorption with predicted flow of digestible amino acids: Scope for improving models. J. Dairy Sci. 89:4747-4757.

Papadopoulos, Y. A., and B. D. McKersie. 1983. A comparison of protein-degradation during wilting and ensiling of 6 forage species. Can. J. Plant Sci. 63:903-912.

Patton, R. A., R. D. McCarthy, and L. C. Griel Jr.. 1970. Observations on rumen fluid, blood serum, and milk lipids of cows fed methionine hydroxy analog. J. Dairy Sci. 53:776-780.

Peñagaricano, F., A. H. Souza, P. D. Carvalho, A. M. Driver, R. Gambra, J. Kropp, K. S. Hackbart, D. Luchini, R. D. Shaver, M. C. Wiltbank, and H. Khatib. 2013. Effect of maternal methionine supplementation on the transcriptome of bovine preimplantation embryos. PLoS One 8:e72302.

Pichard, G. R., B. R. Tesser, C. Vives, C. Solari, A. Hott, and R. E. Larrain. 2006. Proteolysis and characterization of peptidases in forage plants. Agron. J. 98:1392-1399.

Poos-Floyd, M., T. Klopfenstein, and R. A. Britton. 1985. Evaluation of laboratory techniques for predicting ruminal protein degradation. J. Dairy Sci. 68:829-839.

Prange, R. W., M. D. Stern, N. A. Jorgensen, and L. D. Satter. 1984. Site and extent of protein digestion in lactating cows fed alfalfa silage or baled alfalfa hay. J. Dairy Sci. 67:2308-2314.

Raab, L., B. Cafantaris, T. Jilg, and K. H. Menke. 1983. Rumen protein degradation and biosynthesis. 1. A new method for determination of protein degradation in rumen fluid in vitro. Br. J. Nutr. $50: 569-582$ 
Reid, J. T. 1953. Urea as a protein replacement for ruminants: A review. J. Dairy Sci. 36:955-995.

Reid, J. T. 1956. Nutrition and feeding of dairy cattle. J. Dairy Sci. 39:735-763.

Reynolds, C. K., and N. B. Kristensen. 2008. Nitrogen recycling through the gut and the nitrogen economy of ruminants: An asynchronous symbiosis. J. Anim. Sci. 86(E. Suppl.):E293-E305.

Roche, J. R., D. P. Berry, A. M. Bryant, C. R. Burke, S. T. Butler, P. G. Dillon, D. J. Donaghy, B. Horan, K. A. Macdonald, and K. L. Macmillan. 2017. A 100-Year Review: A century of change in temperate grazing dairy systems. J. Dairy Sci. 100:10189-10233. https://doi.org/10.3168/jds.2017-13182.

Roe, M. B., L. E. Chase, and C. J. Sniffen. 1991. Comparison of in vitro techniques to the in situ technique for estimation of ruminal degradation of protein. J. Dairy Sci. 74:1632-1640.

Roffler, R. E., and L. D. Satter. 1975a. Relationship between ruminal ammonia and nonprotein nitrogen utilization by ruminants. I. Development of a model for predicting nonprotein nitrogen utilization by cattle. J. Dairy Sci. 58:1880-1888.

Roffler, R. E., and L. D. Satter. 1975b. Relationship between ruminal ammonia and nonprotein nitrogen utilization by ruminants. II. Application of published evidence to the development of a theoretical model for predicting nonprotein nitrogen utilization. J. Dairy Sci. 58:1889-1898.

Rupel, I. W., G. Bohstedt, and E. B. Hart. 1943. The comparative value of urea and linseed meal for milk production. J. Dairy Sci. 26:647-664.

Russell, J. B., J. D. O’Connor, D. G. Fox, P. J. Van Soest, and C. J. Sniffen. 1992. A net carbohydrate and protein system for evaluating cattle diets: I. Ruminal fermentation. J. Anim. Sci. 70:35513561.

Santos, F. A. P., J. E. P. Santos, C. B. Theurer, and J. T. Huber. 1998. Effects of rumen-undegradable protein on dairy cow performance: A 12-year literature review. J. Dairy Sci. 81:3182-3213.

Santos, K. A., M. D. Stern, and L. D. Satter. 1984. Protein degradation in the rumen and amino acid absorption in the small intestine of lactating dairy cattle fed various protein sources. J. Anim. Sci. $58: 244-255$.

Satter, L. D., and R. E. Roffler. 1975. Nitrogen requirement and utilization in dairy cattle. J. Dairy Sci. 58:1219-1237.

Satter, L. D., and L. L. Slyter. 1974. Effect of ammonia concentration on rumen microbial protein production in vitro. Br. J. Nutr. 32:199-208.

Schwab, C. G. 1995. Protected proteins and amino acids. Pages 115141 in Biotechnology in Animal Feeds and Animal Feeding. R. J. Wallace and A. Chesson, ed. VCH Press, Weinheim, Germany.

Schwab, C. G., P. Huhtanen, C. Hunt, and T. Hvelplund. 2005. Nitrogen requirements of cattle. Pages $13-70$ in Nitrogen and Phosphorus Nutrition of Cattle. E. Pfeffer and A. Hristov, ed. CABI Publishing, Wallingford, UK.

Schwab, C. G., L. D. Satter, and A. B. Clay. 1976. Response of lactating dairy cows to abomasal infusion of amino acids. J. Dairy Sci. 59:1254-1270.

Sibbald, I. R., T. C. Loughheed, and J. H. Linton. 1968. A methionine supplement for ruminants. Pages 453-457 in Proc. 2nd World Conf. Anim. Prod., College Park, MD.

Socha, M. T., D. E. Putnam, B. D. Garthwaite, N. L. Whitehouse, N. A. Kierstead, C. G. Schwab, G. A. Ducharme, and J. C. Robert. 2005. Improving intestinal amino acid supply of pre- and postpartum dairy cows with rumen-protected methionine and lysine. J. Dairy Sci. 88:1113-1126.

Sok, M., D. R. Ouellet, J. L. Firkins, D. Pellerin, and H. Lapierre. 2017. Amino acid composition of rumen bacteria and protozoa in cattle. J. Dairy Sci. 100:5241-5249.

St-Pierre, N. R., and J. T. Sylvester. 2005. Effects of 2-hydroxy4-(methylthio) butanoic acid (HMB) and its isopropyl ester on milk production and composition by Holstein cows. J. Dairy Sci. 88:2487-2497.

Stern, M. D., L. M. Rode, R. W. Prange, R. H. Stauffacher, and L. D. Satter. 1983. Ruminal protein degradation of corn gluten meal in lactating dairy cattle fitted with duodenal T-type cannulae. J. Anim. Sci. 56:194-204.

Stern, M. D., and L. D. Satter. 1984. Evaluation of nitrogen solubility and the Dacron bag technique as methods for estimating protein degradation in the rumen. J. Anim. Sci. 58:714-724.

Storm, E., D. S. Brown, and E. R. Ørskov. 1983. The nutritive value of rumen micro-organisms in ruminants. 3 . The digestion of microbial amino and nucleic acids in, and losses of endogenous from, the small intestine of sheep. Br. J. Nutr. 50:479-485.

Storm, E., and E. R. Ørskov. 1983. The nutritive value of rumen micro-organisms in ruminants. 1. Large scale isolation and chemical composition of rumen micro-organisms. Br. J. Nutr. 50:463-470.

Sullivan, M. L., R. D. Hatfield, and D. A. Samac. 2008. Cloning of an alfalfa polyphenol oxidase gene and evaluation of its potential in preventing postharvest protein degradation. J. Sci. Food Agric. 88:1406-1414.

Sullivan, M. L., and W. E. Zeller. 2013. Efficacy of various naturally occurring caffeic acid derivatives in preventing post-harvest protein losses in forages. J. Sci. Food Agric. 93:219-226.

Tas, M. V., R. A. Evans, and R. F. E. Axford. 1981. The digestibility of amino acids in the small intestine of the sheep. Br. J. Nutr. 45:167-174.

Tedeschi, L. O., L. F. L. Cavalcanti, M. A. Fonseca, M. Herrero, and P. K. Thornton. 2014. The evolution and evaluation of dairy cattle models for predicting milk production: An agricultural model intercomparison and improvement project (AgMIP) for livestock. Anim. Prod. Sci. 54:2052-2067.

Tedeschi, L. O., W. Chalupa, E. Janczewski, D. G. Fox, C. Sniffen, R. Munson, P. J. Kononoff, and R. Boston. 2008. Evaluation and application of the CPM Dairy Nutrition model. J. Agric. Sci. 146:171-182.

Tedeschi, L. O., D. G. Fox, M. A. Fonseca, and L. F. L. Cavalcanti. 2015. Invited Review: Models of protein and amino acid requirements for cattle. Rev. Bras. Zootec. 44:109-132.

Ulrey, C. L., L. Liu, L. C. Andrews, and T. O. Tollefsbol. 2005. The impact of metabolism on DNA methylation. Hum. Mol. Genet. 14:R139-R147.

Van Horn, H. H., D. R. Jacobson, and A. P. Graden. 1969. Influence of level and source of nitrogen on milk production and blood components. J. Dairy Sci. 52:1395-1403.

Vanhatalo, A., P. Huhtanen, V. Toivonen, and T. Varvikko. 1999. Response of dairy cows fed grass silage diets to abomasal infusions of histidine alone or in combinations with methionine and lysine. J. Dairy Sci. 82:2674-2685.

Vik-Mo, L., R. S. Emery, and J. T. Huber. 1974. Milk protein production in cows abomasally infused with casein or glucose. J. Dairy Sci. 57:869-877.

Virtanen, A. I. 1966. Milk production of cows on protein-free feed. Science 153:1603-1614.

Volden, H. 2011. NorFor-The Nordic Feed Evaluation System. EAAP Publication No. 130, Wageningen Academic Publishers, Wageningen, the Netherlands.

Waghorn, G. C. 2008. Beneficial and detrimental effects of dietary condensed tannins for sustainable sheep and goat productionProgress and challenges. Anim. Feed Sci. Technol. 147:116-139.

Wegner, M. I., A. N. Booth, G. Bohstedt, and E. B. Hart. 1940. The "in vitro" conversion of inorganic nitrogen to protein by microorganisms from the cow's rumen. J. Dairy Sci. 23:1123-1129.

White, R. R., Y. Roman-Garcia, J. L. Firkins, P. Kononoff, M. J. VandeHaar, H. Tran, T. McGill, R. Garnett, and M. D. Hanigan. 2017b. Evaluation of the National Research Council (2001) dairy model and derivation of new prediction equations. 2. Rumen degradable and undegradable protein. J. Dairy Sci. 100:3611-3627.

White, R. R., Y. Roman-Garcia, J. L. Firkins, M. J. VandeHaar, L. E. Armentano, W. P. Weiss, T. McGill, R. Garnett, and M. D. Hanigan. 2017a. Evaluation of the National Research Council (2001) dairy model and derivation of new prediction equations. 1. Digestibility of fiber, fat, protein, and nonfiber carbohydrate. J. Dairy Sci. 100:3591-3610. 
Williams, L. R., F. A. Martz, and E. S. Hilderbrand. 1970. Feeding encapsulated methionine supplement to lactating cows. J. Dairy Sci. 53:1709-1713.

Woll, F. W. 1918. Alfalfa as a sole feed for dairy cattle. J. Dairy Sci. 1:447-461.

Zhou, Z., O. Bulgari, M. Vailati-Riboni, E. Trevisi, M. A. Ballou, F. C. Cardoso, D. N. Luchini, and J. J. Loor. 2016a. Rumen-protected methionine compared with rumen-protected choline improves immunometabolic status in dairy cows during the peripartal period. J. Dairy Sci. 99:8956-8969.

Zhou, Z., M. Vailati-Riboni, E. Trevisi, J. K. Drackley, D. N. Luchini, and J. J. Loor. 2016b. Better postpartal performance in dairy cows supplemented with rumen-protected methionine compared with choline during the peripartal period. J. Dairy Sci. 99:8716-8732.

\section{APPENDIX}

Table A1. Timeline of significant advances in protein and amino acid nutrition

\begin{tabular}{|c|c|c|}
\hline Date & Milestone & Reference \\
\hline 1920 & Amounts of digestible CP needed to produce $1 \mathrm{lb}$ of milk are proposed. & McCandlish, 1920 \\
\hline 1921 & Forty years of research on proteins and NPN compounds in feeds is reviewed. & Nevens, $1921 \mathrm{a}, \mathrm{b}$ \\
\hline 1940 & $\begin{array}{l}\text { Confirmed that urea is degraded to ammonia in the rumen and the ammonia can be } \\
\text { used for bacterial protein synthesis }\end{array}$ & Wegner et al., 1940 \\
\hline 1943 & Feed proteins are shown to differ in ruminal degradation & Rupel et al., 1943 \\
\hline 1952 & Classification of EAA and NEAA is shown to be similar to that in nonruminants. & Black et al., 1952 \\
\hline 1954 & Heat is used to reduce ruminal degradation of feed proteins. & Chalmers et al., 1954 \\
\hline 1956 & $\begin{array}{l}\text { Shown that most CP in grasses and legumes is soluble and solubility increases with } \\
\text { ensiling. }\end{array}$ & Kemble, 1956 \\
\hline 1959 & $\begin{array}{l}\text { Research confirms that blood urea can be transferred to the rumen and again used } \\
\text { for microbial protein synthesis. }\end{array}$ & Houpt, 1959 \\
\hline 1966 & Research confirms that rumen bacteria provide all AA but content of histidine is low. & Virtanen, 1966 \\
\hline 1970 & First rumen-protected methionine supplement is fed to lactating dairy cows. & Broderick et al., 1970 \\
\hline 1974 & Metabolizable protein (MP) system is proposed. & Burroughs et al., 1975 \\
\hline 1974 & Ammonia requirements for rumen bacteria are identified. & Satter and Slyter, 1974 \\
\hline 1975 & A model is developed and evaluated for predicting utilization of supplemental urea. & $\begin{array}{l}\text { Roffler and Satter, } \\
1975 a, b\end{array}$ \\
\hline 1976 & $\begin{array}{l}\text { Methionine and lysine are confirmed as first-limiting AA for cows fed corn-based } \\
\text { diets. }\end{array}$ & Schwab et al., 1976 \\
\hline 1979 & In situ method is established for measuring rate and extent of protein degradation. & $\begin{array}{l}\text { Ørskov and McDonald, } \\
1979\end{array}$ \\
\hline 1981 & $\begin{array}{l}\text { Flows of AA to the duodenum are measured in cows fed diets with different protein } \\
\text { supplements. }\end{array}$ & Arambel and Coon, 1981 \\
\hline
\end{tabular}


Table A1 (Continued). Timeline of significant advances in protein and amino acid nutrition

\begin{tabular}{|c|c|c|}
\hline Date & Milestone & Reference \\
\hline 1982 & Wilting forage before ensiling reduces the rate of protein breakdown. & $\begin{array}{l}\text { McKersie and Buchanan- } \\
\text { Smith, } 1982\end{array}$ \\
\hline 1992 & $\begin{array}{l}\text { Research confirms that peptides and free AA stimulate rumen microbial protein } \\
\text { synthesis. }\end{array}$ & Russell et al., 1992 \\
\hline 1995 & A 3-step approach is described for measuring intestinal digestibility of feed proteins. & $\begin{array}{l}\text { Calsamiglia and Stern, } \\
1995\end{array}$ \\
\hline 1999 & $\begin{array}{l}\text { Histidine is identified as first-limiting AA when cows are fed non-corn diets without } \\
\text { protein supplements. }\end{array}$ & Vanhatalo et al., 1999 \\
\hline 2001 & $\begin{array}{l}\text { New NRC model allows balancing diets for RDP, RUP, and targeted concentrations of } \\
\text { EAA in MP. }\end{array}$ & NRC, 2001 \\
\hline 2013 & $\begin{array}{l}\text { The greatest production and health benefits to AA balancing are seen in early fresh } \\
\text { cows. }\end{array}$ & Osorio et al., 2013 \\
\hline 2014 & $\begin{array}{l}\text { Literature review indicated that future protein models must consider differences in } \\
\text { metabolism and use of individual AA. }\end{array}$ & Arriola Apelo et al., 2014 \\
\hline 2017 & $\begin{array}{l}\text { Literature review indicated large difference in AA composition of rumen bacteria } \\
\text { and protozoa. }\end{array}$ & Sok et al., 2017 \\
\hline
\end{tabular}

